\title{
Private Well/Spring Position PAPER Rifle, Colorado, Sites
}

May 1995

DISTRIBUTION OF THIS DOCUMENT IS UNLIMITED, 


\section{INTENDED FOR PUBLIC RELEASE}

This report has been reproduced from the best available copy. Available in paper copy and microfiche

Number of pages in this report: 53

DOE and DOE contractors can obtain copies of this report from:

Office of Scientific and Technical Information

P.0. Box 62

Oak Ridge, TN 37831

(615) 576-8401

This report is publicly available from:

National Technical Information Service

Department of Commerce

5285 Port Royal Road

Springfield, VA 22161

(703) 487-4650 


\section{DISCLAIMER}

Portions of this document may be illegible in electronic image products. Images are produced from the best available original document. 


\title{
PRIVATE WELL/SPRING POSITION PAPER RIFLE, COLORADO, SITES
}

May 1995

\author{
Prepared for \\ U.S. Department of Energy \\ UMTRA Project \\ Albuquerque, New Mexico \\ Prepared by \\ Jacobs Engineering Group Inc. \\ Albuquerque, New Mexico
}

\section{DISCLAIMER}

This report was prepared as an account of work sponsored by an agency of the United States Government. Neither the United States Government nor any agency thereof, nor any of their employees, makes any warranty, express or implied, or assumes any legal liability or responsibility for the accuracy, completeness, or usefulness of any information, apparatus, product, or process disclosed, or represents that its use would not infringe privately owned rights. Reference herein to any specific commercial product, process, or service by trade name, trademark, manufacturer, or otherwise does not necessarily constitute or imply its endorsement, recommendation, or favoring by the United States Government or any agency thereof. The views and opinions of authors expressed herein do not necessarily state or reflect those of the United States Government or any agency thereof. 


\section{EXECUTIVE SUMMARY}

This position paper describes the hydrogeochemical relationship between the New and Old Rifle processing sites and 15 domestic wells in their vicinity. The relationship of the domestic wells to the Old and New Rifle tailings sites requires clarification due to recent advances in understanding of Rifle site conceptual models. Findings of the original Rifle baseline risk assessment completed in March 1992 were based on a limited understanding of background water quality and on-site and regional hydrogeologic regimes.

In order to form a bridge from the Rifle remedial action plan (RAP) and the recent baseline risk assessment to this position paper, several issues require discussion.

First, through analysis of long-term ground water level data, the hydraulic gradient between the former tailings and private wells and springs was assessed. Water level data indicate that the hydraulic gradient between wells north of Highway 6 and the former tailings pile is constant to the southwest regardless of the stage of the Colorado River.

Second, in the Rifle RAP there was not a strong emphasis placed on describing regional influences on water quality in the vicinity of the processing sites. This document uses available information coupled with theory of regional ground water flow to describe regional flow systems north of Rifle.

Third, the definition of background water quality from the RAP has been refined in several ways. For purposes of the recent baseline risk assessment, wells found to be either close to the Colorado River or not in representative flow systems were eliminated from the background assessment. Also, for the recent baseline risk assessment, all alluvial wells used to define background for the sites were located east of Old Rifle. In the RAP, alluvial background wells were also placed between the sites (downgradient of Old Rifle). Two additional wells were installed for the recent baseline risk assessment upgradient of Old Rifle which verified that several of the older wells (RF0-01-0597 and -0598) were in locations representative of background. The definition of background had to be further refined for this assessment because the majority of private wells and springs are located in different hydrogeologic regimes than are the processing sites for which original background water quality estimates were used. The former tailings piles were placed on alluvium. In order to determine background for the tailings sites wells were placed in upgradient alluvium and Wasatch beds which could be correlated with those beneath and downgradient of the piles. The majority of private wells and springs are completed or occur in different (usually higher) flow systems within the Wasatch Formation. Therefore, background locations for this assessment were selected upgradient from the Old Rifle site within the uppermost Wasatch Formation flow systems.

As a result of further definition of ground water flow and background water quality, the following conclusions regarding impact of private wells and springs in the vicinity of Rifle processing sites have been made. 
- None of the private wells or springs, with the possible exception of private well RFN01-0428, appear to have been impacted by former uranium processing activities.

- Regional geologic data support the existence of natural contaminants in background water near Rifle. The probable source for the uranium and other metals (including chromium, vanadium, selenium), which are commonly associated with the occurrence of uranium deposits, is through erosion of units containing uranium ore deposits and subsequent deposition in the Wasatch Formation.

- Statistical analyses performed on all on-site and downgradient constituents (including radionuclides), found to be above background in the recent Rifle baseline risk assessment indicate that constituents related to processing activities are not elevated above background in private wells and springs.

Based on the above conclusions it is recommended that DOE continue sampling well RFN01-0428 annually until the site observational work plan is completed. At this time, the potential impact to RFN-01-0428 will be reassessed. DOE should discontinue sampling all other private wells and springs north of Highway 6 or upgradient of the New Rifle site. 
Section

Page

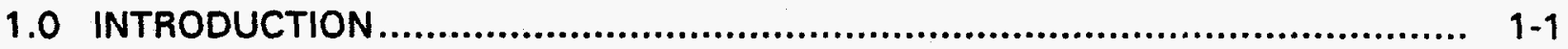

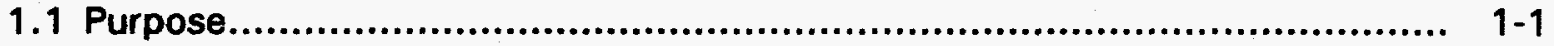

1.2 Scope ................................................................................ $1-1$

1.3 Previous risk evaluation .......................................................... 1-1

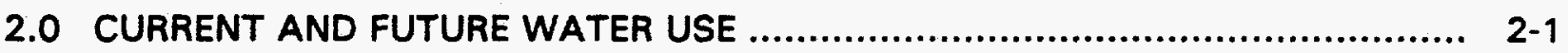

2.1 Current water use ..................................................................... $2-1$

2.2 Future water use................................................................... $2-4$

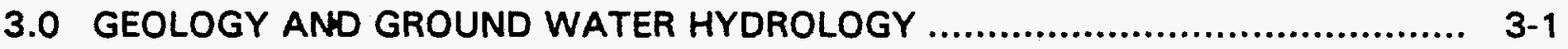

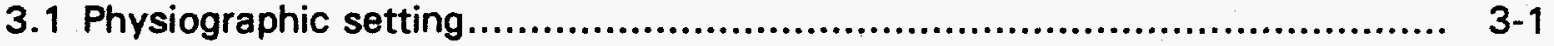

3.2 Regional geology ................................................................... $3-1$

3.3 Regional hydrogeology........................................................... $3-4$

3.4 Geologic setting in the vicinity of private wells and springs..................... $3-4$

3.5 Hydrogeologic setting in the vicinity of private wells and springs............... $3-7$

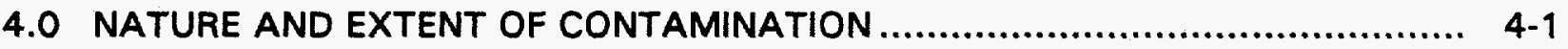

4.1 Background water quality....................................................... $4-1$

4.1.1 Alluvial background water .............................................. 4-1

4.1.2 Wasatch background water............................................... 4-2

4.1.3 Background for private water sources north or east of New Rifle...... 4-2

4.1.4 Comparison with regional background water ............................ 4-3

4.2 Nature and extent of site-related contamination.................................. 4-3

4.2.1 Possible site contamination of private well RFN-01-0428 .............. 4-7

5.0 STATISTICAL COMPARISON OF BACKGROUND WATER QUALITY

WITH PRIVATE WATER QUALITY NORTH TO EAST OF SITE $\ldots \ldots \ldots \ldots \ldots \ldots \ldots \ldots . . \quad 5-1$

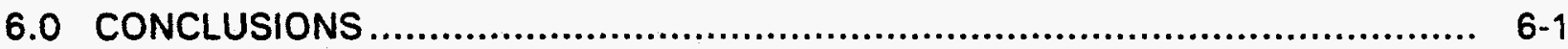

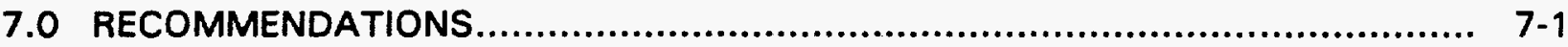

8.0 LIST OF CONTRIBUTORS ........................................................ 8 .1

9.0 REFERENCES ........................................................................ $9-1$ 


\section{LIST OF FIGURES}

Figure

2.1 Private wells/springs and selected DOE wells/springs near Rifle, Colorado, sites.. 2-2

2.2 City and county land use zoning, New Rifle, Colorado, site

3.1 Regional hydrologic drainage north of Old and New Rifle, Colorado, processing sites

3.2 Geologic cross section, Rifle, Colorado, sites and region north

3.3 Location of profile A-A', New Rifle, Colorado, site

3.4 Generalized geologic cross section A-A' (southwest to northeast), New Rifle, Colorado, site

3.5 Water table contour map of the alluvial aquifer, Old Rifle, Colorado, processing site vicinity

3.6 Water table contour map of the alluvial aquifer, New Rifle, Colorado, processing site vicinity

4.1 Uranium isopleth map for the alluvial aquifer, Old Rifle, Colorado, site, March 1992

4.2 Uranium isopleth map for the alluvial aquifer, New Rifle, Colorado, site, March 1994

4.3 Uranium isopleth map for the Wasatch formation at New Rifle, Colorado, site, March 1994

5.1 Boxplots of sulfate concentrations in background and private wells in the vicinity of the New Rifle, Colorado, site, 1990-1994

5.2 Boxplots of uranium concentrations in background and private wells in the vicinity of the New Rifle, Colorado, site, 1990-1994

5.3 Boxplots of molybdenum concentrations in background and private wells in the vicinity of the New Rifle, Colorado, site, 1990-1994

5.4 Boxplots of combined radium-226 and -228 concentrations in background and private wells in the vicinity of the New Rifle, Colorado, site, 1990-1994 


\section{LIST OF TABLES}

\section{Table}

2.1 Available well construction information for private wells near Rifle,

Colorado, sites ................................................................................... $2-3$

5.1 Summary of water quality for background and private water locations, Rifle, Colorado, sites $(08 / 90-12 / 94)$ 
PRIVATE WELLSPRING POSITION PAPER

RIFLE, COLORADO, SITES

LIST OF ACRONYMS

LIST OF ACRONYMS

Acronym

AlI

ANOVA

bogs

DOE

EPA

$M C L$

RAP

SDWA

UMTRA
Definition

agricultural/industrial

analysis of variance

below ground surface

U.S. Department of Energy

U.S. Environmental Protection Agency

maximum concentration limit

remedial action plan

Safe Drinking Water Act

Uranium Mill Tailings Remedial Action

DOE/AL/62350-190

1-May-95

REV. 0 , YER. 3

015D3WP.DOC (RFC)

-iv- 


\subsection{INTRODUCTION}

\subsection{PURPOSE}

The purpose of this position paper is to describe the hydrogeochemical relationship between the New and Old Rifle processing sites and 15 domestic wells in their vicinity. Results of this assessment will be used as a decision making/planning tool regarding the U.S. Department of Energy's (DOE) role in providing potable water to area residents.

The relationship of the domestic wells to the Old and New Rifle tailings sites requires clarification due to recent advances in understanding of Rifle site conceptual models. Findings of the original Rifle baseline risk assessment completed in March 1992 were based on a limited understanding of background water quality and the on-site and regional hydrogeologic regimes. Although there are remaining data gaps in a full characterization of the Rifle sites, background water quality has been further defined as a result of more recent baseline risk assessment activities and activities associated with this assessment. Installation of background and downgradient monitor wells, increased sampling, further definition of horizontal and vertical hydraulic gradients, statistical analysis, and expanded review of existing literature all enhanced understanding of the Rifle conceptual models.

\subsection{SCOPE}

The scope of work for this assessment includes the following:

- Description of the regional and local influences on ground water flow and background water quality near private wells and springs.

- Detailed assessment of the quality of private water supplies near the processing sites, including a geochemical and statistical comparison to background ground water.

- Conclusions and recommendations.

\subsection{PREVIOUS RISK EVALUATION}

A risk evaluation was conducted in 1992 to identify immediate risks resulting from ground water contamination from previous processing site activities (DOE, 1992a). The results of the 1992 risk evaluation were based on limited available data, without a complete assessment of background ground water quality and ground water flow. As a result, constituent levels in upgradient and crossgradient private wells and springs were conservatively assumed to indicate site-related impacts and potential site-related health risks. 
As a result of the recent Rifle risk assessment and further refinement of site conceptual models, background water quality and ground water flow gradients near the Rifle sites are much more clearly understood. Therefore, determination of the potential for impact to private water supplies near the Rifle sites can now be made with certainty. 


\subsection{CURRENT AND FUTURE WATER USE}

\subsection{CURRENT WATER USE}

A total of 16 domestic wells and ground water springs were monitored from 1991 through March 1995 as part of the DOE's Surface and Ground Water Projects (Figure 2.1). Figure 2.1 also shows Old and New Rifle DOE background wells and springs and downgradient DOE monitor wells pertinent to this investigation. Of these 16 private wells, 15 are in the vicinity of the New Rifle processing site and one, well RFO-01-0436, is in the vicinity of the Old Rifle processing site. Three of the residences and businesses using private water supplies near the New Rifle site have been connected to the city of Rifle water system. Wells at these residences or businesses include RFN-01-0560, -0423, and -0432. Well RFN-01-0559 has been decommissioned.

Seven of the remaining twelve private wells and springs in the vicinity of the Rifle sites are at residences. Residential wells include RFO-01-0436, northeast of Old Rifle; well RFN-01-0421, east of New Rifle; wells RFN-01-0430 and -0431 , northeast of New Rifle; and springs RFN-01-0426, -0433 , and -0435 , also north or northeast of New Rifle. The owner of RFN-01-0426 treats the water by reverse osmosis before drinking. The other well and spring owners report that their wells are not used for drinking water, except for very rare occasions such taking a small drink from an outside hose. Private water supplies at these residences are used primarily for bathing, showering, and for watering plants and livestock.

Five private wells near New Rifle are currently used for industrial purposes. These wells are RFN-01-0422, east of New Rifle; RFN-01-0424 and -0425, northeast of New Rifle; RFN-01-0427, northwest of New Rifle; and RFN-01-0428, approximately 2.7 miles west of New Rifle. According to their owners, no one drinks the water from the wells.

Data are limited concerning the exact details of private well construction. However completion depths have been obtained for most wells from available well completion reports or from well owners (Table 2.1). Wells north of the processing sites tend to be completed between 50 and 80 feet ( $\mathrm{ft}$ ) below ground surface (bgs). This would place most wells north of Highway 6 in shallow Wasatch Formation or Wasatch colluvium. An exception to this is well RFN-01-0560, which is completed at $130 \mathrm{ft}$ bgs. Because well RFN-01-0560 is a significant distance from other wells and completed much deeper, it most likely is completed in an entirely different hydrostratigraphic unit. Wells south of Highway 6 are completed near the alluvium Wasatch contact (e.g., RFN-01-

0421 and -0428 ) or deeper in the Wasatch Formation (e.g., well RFN-01-0422), which reportedly is completed at $160 \mathrm{ft}$ bgs.

Information regarding exact screened intervals is not available. However, because these wells were constructed for water supply purposes, they may be 

Table 2.1 Available well construction information for private wells near Rifle, Colorado, sites

\begin{tabular}{|c|c|c|c|c|c|c|}
\hline Location ID & $\begin{array}{c}\text { Reported } \\
\text { Completion } \\
\text { Depth (ft) }\end{array}$ & $\begin{array}{l}\text { Probable form } \\
\text { of completion }\end{array}$ & Use & $\begin{array}{l}\text { Regularly } \\
\text { used for } \\
\text { drinking? } \\
\text { Yes/No" }\end{array}$ & $\begin{array}{c}\text { Used for } \\
\text { any } \\
\text { purpose? } \\
\text { Yes/No }\end{array}$ & Flow relation \\
\hline \multicolumn{7}{|l|}{ New Rifle } \\
\hline $\begin{array}{l}\text { RFN-01-0559 } \\
\text { RFN-01-0560 } \\
\text { RFN-01-0421 } \\
\text { RFN-01-0422 } \\
\text { RFN-01-0423 } \\
\text { RFN-01-0424 } \\
\text { RFN-01-0425 } \\
\text { RFN-01-0426 } \\
\text { RFN-01-0427 } \\
\text { RFN-01-0428 } \\
\text { RFN-01-0430 } \\
\text { RFN-01-0431 } \\
\text { RFN-01-0432 } \\
\text { RFN-01-0433 } \\
\text { RFN-01-0435 }\end{array}$ & $\begin{array}{c}130 \\
25 \\
160 \\
20 \\
60 \\
65 \\
\text { NA } \\
68 \\
30 \\
? \\
80 \\
55 \\
\text { NA } \\
\text { NA }\end{array}$ & $\begin{array}{c}\text { Decomn } \\
\text { W } \\
\text { W } \\
\text { Colluvium } \\
\text { UW } \\
\text { UW } \\
\text { UWa } \\
\text { UW } \\
\text { A } \\
? \\
\text { UW } \\
\text { UW } \\
\text { UWa } \\
\text { UWa }\end{array}$ & $\begin{array}{c}\text { nissioned } \\
\text { I } \\
\text { F } \\
\text { I } \\
\text { R } \\
\text { I } \\
\text { I } \\
\text { R } \\
\text { I } \\
\text { I } \\
\text { R } \\
\text { R } \\
\text { R } \\
\text { R } \\
\text { R }\end{array}$ & $\begin{array}{c}\text { d } \\
\text { no } \\
\text { no } \\
\text { no } \\
\text { no } \\
\text { no } \\
\text { no } \\
\text { yes } \\
\text { no } \\
\text { no } \\
\text { no } \\
\text { no } \\
\text { no } \\
\text { no } \\
\text { no }\end{array}$ & $\begin{array}{l}\text { no } \\
\text { yes } \\
\text { yes } \\
\text { yes } \\
\text { yes } \\
\text { yes } \\
\text { yes } \\
\text { no } \\
\text { yes } \\
\text { yes } \\
\text { yes } \\
\text { yes } \\
\text { yes } \\
\text { yes }\end{array}$ & $\begin{array}{l}C \\
C \\
U \\
U \\
U \\
U \\
U \\
U \\
C \\
D \\
U \\
U \\
U \\
U \\
U\end{array}$ \\
\hline \multicolumn{7}{|l|}{ Old Rifle } \\
\hline RFO-01-0436 & 72 & UW & $R$ & & & $\mathrm{U}$ \\
\hline
\end{tabular}

Based on recent telephone conversations with local residents.

bspring.

'Drink after treated by Reverse Osmosis Unit.

U - upgradient.

D - downgradient.

NA - not applicable.

C - crossgradient.

I - industrial.

$R$ - residential.
F - Residential/farmyard.

A - alluvial aquifer.

UW - upper Wasatch.

W- deeper Wasatch.

? - unknown.

UWa - upper Wasatch above site aquifer. 
screened across several water bearing zones. Water quality from such wells would be a composite from the various zones. The dominant influences on water quality would come from zones capable of yielding the most water.

\subsection{FUTURE WATER USE}

Figure 2.2 shows city and county zoning areas adjacent to and west of the New Rifle site. All land near the New Rifle site is currently zoned agricultural/industrial (A/I) except the areas immediately north of Highways 6 and 24 and the New Rifle site, which are zoned residential, general commercial, and light industrial. Land zoned as $A / /$ can be used for residential purposes on lots of 2 acres or more. Industrial use requires special approval by the county and is limited to activities involved with natural resource extraction, such as mining of the existing gravel pits. Land use and therefore water use changes in the near future are not expected.

The city of Rifle has considered various plans for using the New Rifle site. Among the uses under consideration are a 10-hole golf course (at the New Rifle site), an 18-hole golf course (New Rifle site and adjacent property), and a park and nature trail area (New Rifle site). Golf course development would require water for irrigating the course.

The city is considering the use of the sewage lagoon wastewater as irrigation water for either a park or golf course in lieu of discharging the effluent directly to the Colorado River, and to reduce the need for potable water supplies for irrigation. This wastewater reuse also would help the city meet future wastewater effluent quality improvement requirements.

Figure 2.2 shows the location of the city wastewater sewage lagoons. Development of the properties west of these lagoons for higher density land use than agricultural/rural (2-acre minimum lot size), will require installation of central water and wastewater systems and probably would require connection to the existing city lagoons. Large-scale residential development of land zoned $A / l$ is unlikely in the next 10 years. 


\subsection{GEOLOGY AND GROUND WATER HYDROLOGY}

\section{$3.1 \quad$ PHYSIOGRAPHIC SETTING}

The Rifle area is located along the northeastern edge of the Colorado Plateau Physiographic Province near its boundary with the Southern Rocky Mountain Physiographic Province. The principal physiographic elements of this assessment include the Colorado River Valley, the Grand Hogback monocline that forms the western boundary of the Southern Rocky Mountain Physiographic Province, and the White River Plateau (Figure 3.1).

The region north of the Rifle sites is characterized by mature, stream-eroded upland pediment surfaces; large structural upwarps; and intervening basins. Topographic elevations in the region range from $5400 \mathrm{ft}$ above sea level along the Colorado River near the former Rifle processing sites to $8000 \mathrm{ft}$ above sea level along the Grand Hogback monocline to $10,500 \mathrm{ft}$ above sea level along the White River Plateau. Figure 3.1 illustrates this topographic variability.

\subsection{REGIONAL GEOLOGY}

Quaternary deposits near the Rifle sites are represented by sediments consisting of pediment gravels of several ages, glacial drift and outwash, landslide deposits, fluvially deposited alluvium, and colluvium. Four levels of river terraces and associated pediments which formed during two glacial advances are present in the Rifle area (Sinnock, 1981).

Pediment deposits consist of coarse gravel, cobbles, and boulders in a clayey-silt matrix. Unconsolidated fluvial alluvium is present along the Colorado River Channel and along major tributaries such as Rifle Creek. Near Rifle, the alluvium is approximately 16 to $25 \mathrm{ft}$ thick (DOE, $1992 \mathrm{~b}$ ).

Although it is not present at the Rifle sites, northwest of Rifle the more resistant Green River Formation overlies strata of the Wasatch Formation, forming the prominent cliffs that are apparent from the Rifle sites and the Colorado River (Figure 3.11. The Tertiary Green River Formation consists of oil shales, sandstones, and marlstones.

Figure 3.2 shows a generalized cross section of the region directly north of the Rifle sites. Shallow bedrock in the southern part of the region (generally between the Colorado River and the Grand Hogback monocline) consists of variegated claystone, siltstone, and fine-grained sandstone of the Wasatch Formation. The Wasatch Formation was deposited concurrently with regional uplift, generally from the Paleocene through the Eocene epochs. Formations rich in uranium and associated metals were eroded and deposited as interbedded shales and sandstones. Although the Wasatch Formation contains some resistant beds that form cliffs, most of the formation weathers easily and has formed lowland mesas (including Prefontaine and Graham mesas), which are 


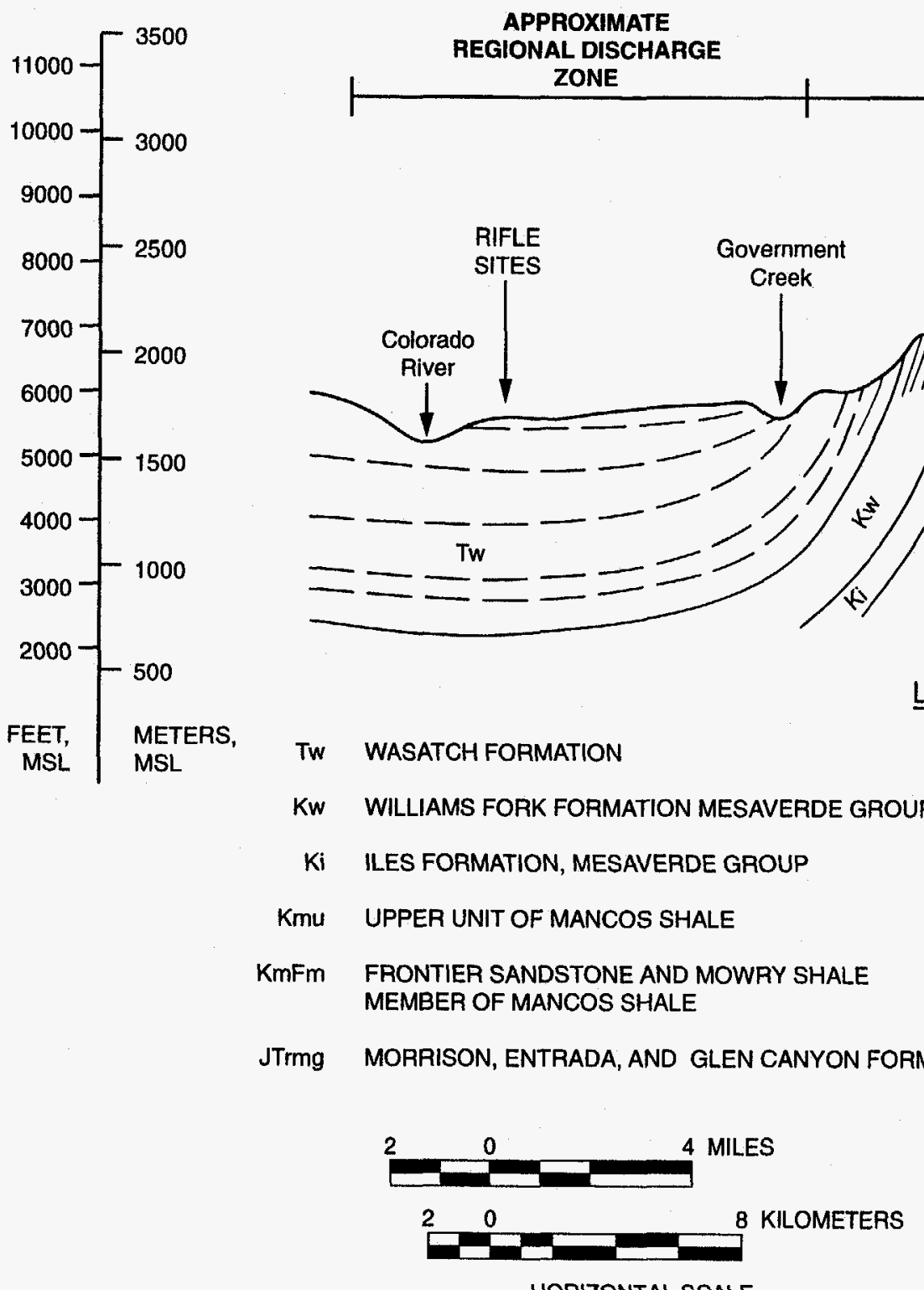

APPROXIMATE

REGIONAL RECHARGE ZONE

HORIZONTAL SCALE

FIGURE 3.2

PFW WE WEBER SANDSTONE AND MAROON FORMATION

Pm MINTURN FORMATION

Pb BELDEN FORMATION

MDr MISSISSIPPIAN AND DEVONIAN ROCKS

$\mathrm{MEr}$ MISSISSIPPIAN AND CAMBRIAN ROCKS

/// Fault/Fracture ZONE

— - estimated diP OF BEDDING

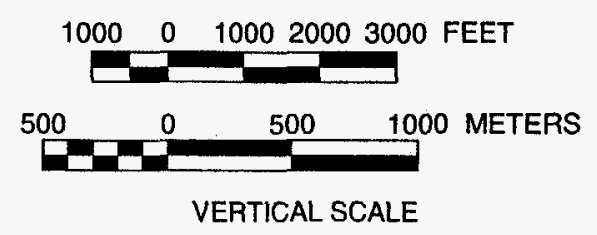

GEOLOGIC CROSS SECTION

RIFLE, COLORADO, SITES AND REGION NORTH 
directly northwest and northeast of the city of Rifle. The sedimentary beds of the Wasatch Formation generally dip gently southwest (toward the axis of the Colorado River Basin) in the vicinity of the sites. However, the dip steepens rapidly to a near-vertical orientation along the face of the Grand Hogback monocline.

Numerous faults cutting Precambrian to Tertiary bedrock occur along the Grand Hogback monocline and landslide deposits occur on the steeply dipping rock surfaces. Directly north of the Grand Hogback and extending another 6 miles north are a series of near-vertically dipping beds of late Permian, Mesozoic, and Cambrian age. Included are the vanadium, and uranium-bearing Morrison and Entrada Formations (Figure 3.2). Figure 3.1 shows the location of beds of the Entrada Sandstone, which contain developed vanadium and uranium deposits.

\subsection{REGIONAL HYDROGEOLOGY}

Regional ground water flow north of the Rifle sites is complex due to structural, topographic, and geologic variation. There is little detailed information on the hydrogeologic systems within the region surrounding Rifle. Figure 3.1 approximates the limit of the regional ground water basin. The White River uplift and Grand Hogback are in a zone of regional recharge, while the Colorado River and vicinity are in a zone of regional discharge.

The hydrologic drainage basin north of the Rifle sites has well defined local relief and as evidenced by features such as the Colorado River and numerous creeks and springs, a number of different flow systems discharge toward the river in the vicinity of the Rifle sites. Ground water flow paths are longer in regional and intermediate ground water flow systems than in local systems. The degree of ground water mineralization at a specific discharge area is a function of both the initial water chemistry and the length of time the water is in contact with various rock types along its flow path. The numerous flow systems, with varying flow path depths and lengths within the interbedded shales and sandstones of the Wasatch Formation, cause the variability in ground water quality in the Rifle area.

\subsection{GEOLOGIC SETTING IN THE VICINITY OF PRIVATE WELLS AND SPRINGS}

In general, private wells in the vicinity of the Old and New Rifle tailings sites are completed in Wasatch colluvium and interbedded shales and sandstones of the Wasatch Formation. Natural springs (some privately owned) discharge from bluffs north of the site along bedding surfaces in the Wasatch Formation. These depositional facies near the New Rifle site are shown in cross section in Figures $\mathbf{3 . 3}$ and $\mathbf{3 . 4}$.

According to available well construction information (Table 2.1), New Rifle private wells RFN-01-0421 and -0428 most likely are completed in floodplain alluvium near the interface of the Wasatch Formation. The alluvium, which directly overlies the Wasatch Formation at the Rifle sites, ranges from about 


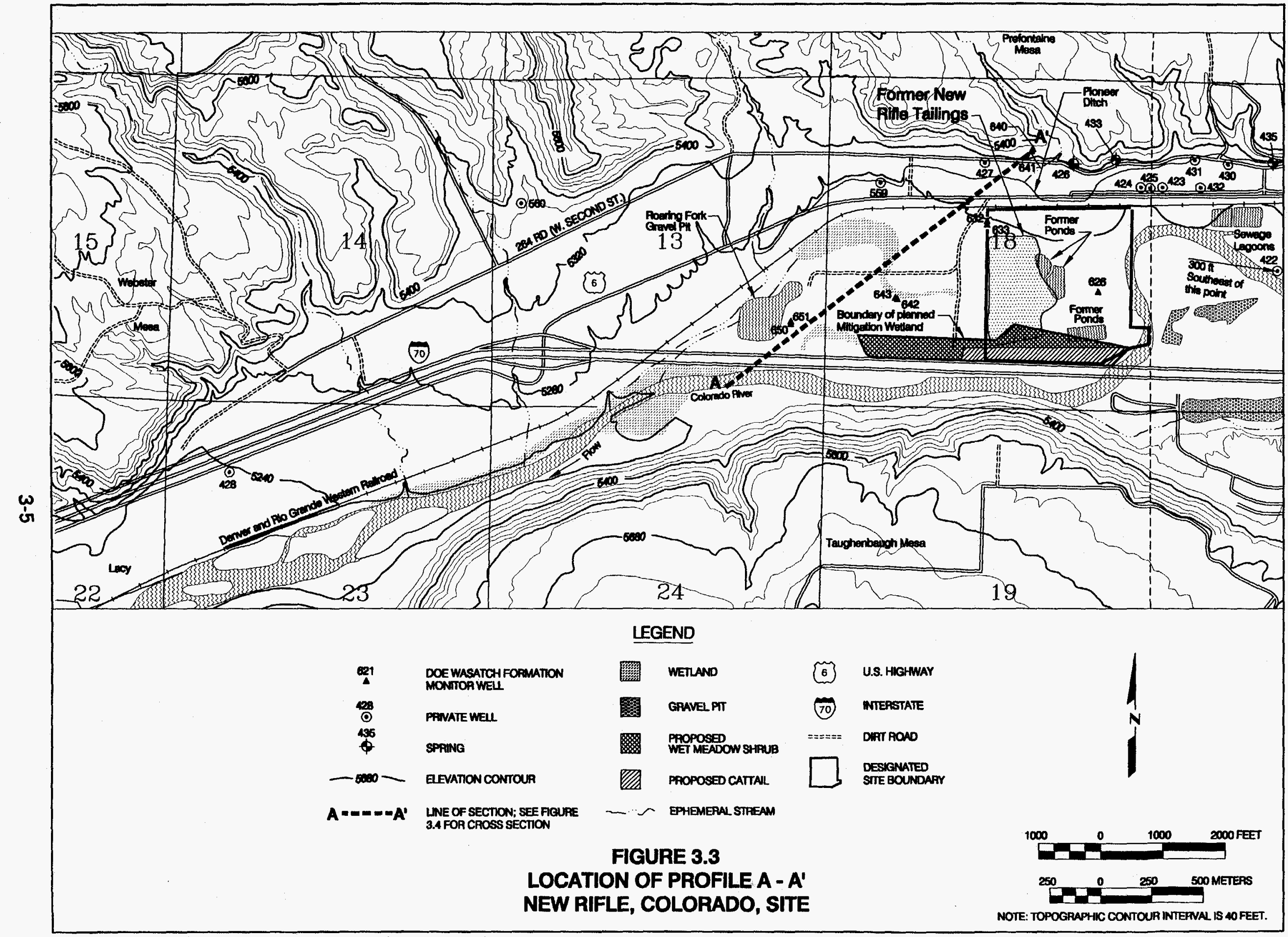

PC: H: \USER \SSUNIGA \RFL \POSTRAP\NRAAPRIM.OWG (MWELL-LOCMAP) 4-25-95 


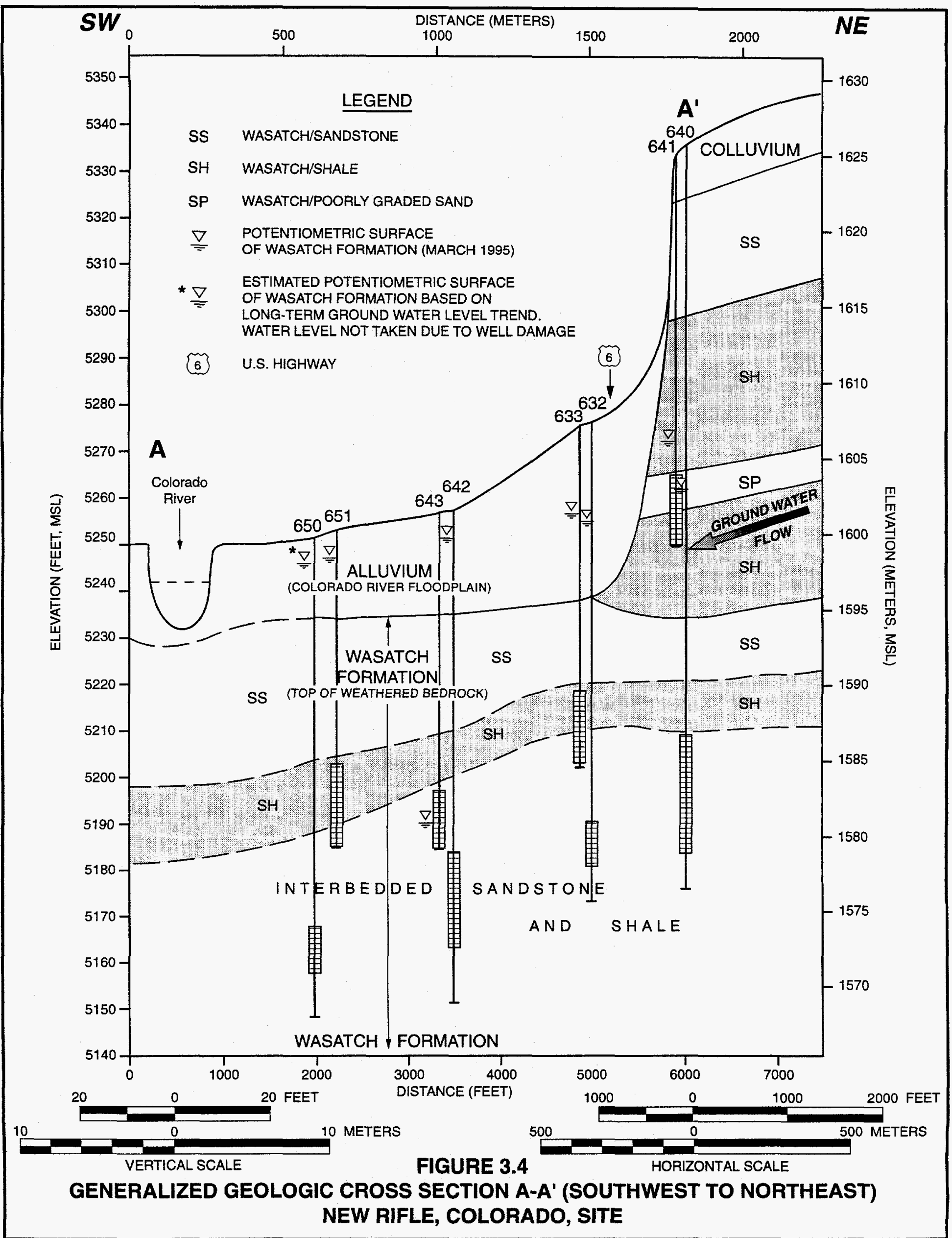


20 to $35 \mathrm{ft}$ thick. The alluvium in the vicinity of the New Rifle site was deposited in a broad floodplain that pinches out a short distance north of Highway 6.

Wells and springs north of Highway 6 generally tap only the Wasatch Colluvium or shallow interbedded shales and sandstones of the Wasatch Formation. The bedrock surface and bedding of the weathered Wasatch Formation north of New Rifle dip toward the southwest (Figure 3.4). The upper weathered beds of the Wasatch Formation are composed of sandstone and are underlain by shale. DOE geologic logs indicate that weathered sandstone is soft, crumbly, and moist.

The deeper beds of the Wasatch Formation near the former Rifle processing sites consist of over $2000 \mathrm{ft}$ of interbedded shales and lenticular sandstone units dipping 5 to 10 degrees to the west-southwest. The upper Shire Member is $1600 \mathrm{ft}$ thick near Rifle and consists of variegated claystones, siltstones, and lenticular sandstones (DOE, 1992b).

\subsection{HYDROGEOLOGIC SETTING IN THE VICINITY OF PRIVATE WELLS AND SPRINGS}

In general, there are two water-bearing hydrogeologic units in the vicinity of the private wells and springs and the Rifle processing sites: a shallow unconfined aquifer in the alluvium lining the Colorado River and a semiconfined aquifer in the Wasatch Formation bedrock beneath the alluvium. Thirteen of the fifteen private wells in the vicinity of the Rifle processing sites are completed in the Wasatch Formation or colluvium of the Wasatch Formation. Because well RFN-01-0560 is a significant distance from other wells and is completed much deeper, it is most likely completed in an entirely different hydrostratigraphic unit within the Wasatch Formation. Based on long-term ground water level trend analysis in the vicinity of the New Rifle site, there is no potential for impact from tailings seepage.

In contrast to the Old Rifle site, New Rifle alluvial sediments are deposited in a broad floodplain that extends several miles downgradient. The upper Wasatch Formation at both sites is weathered and although it has a lower hydraulic conductivity, it is in direct hydraulic contact with the alluvium. Therefore, the upper Wasatch and alluvium are sometimes indistinguishable when ground water quality or ground water level data are analyzed.

The alluvium is recharged by precipitation, regional ground water flow from upgradient water-bearing beds of the Wasatch Formation, and return irrigation flow. At Old Rifle, the site also may be recharged occasionally by upgradient lagoons on Graham Mesa. Seasonal fluctuations in the Colorado River may locally recharge the alluvium during periods of high stage.

The Wasatch Formation is recharged by precipitation where it is exposed north of Highway 6, upgradient base-flow, by return irrigation flow, and by the alluvial 
aquifer. The occurrence of return irrigation flow is especially noteworthy north of Highway 6 in the area where many private wells are located. Pioneer Ditch routes water from Rifle Creek to users of irrigation water along Highway 6 and 264 Road (Figure 3.3). Recharge from Pioneer Ditch likely causes a local ground water high, further elevating ground water in the Wasatch Formation as it flows downdip toward the Colorado River.

Ground water in the alluvium and Wasatch Formation at the Old and New Rifle sites flows southwest. The ultimate discharge area for the alluvium and upper Wasatch Formation is the Colorado River. The saturated horizontal hydraulic gradient in the alluvial aquifer and in the upper Wasatch Formation ranges from 0.002 to 0.006 feet per foot $(\mathrm{ft} / \mathrm{ft})(\mathrm{DOE}, 1992 \mathrm{~b})$. During times of high river stage, ground water flow near the river likely parallels the river. During periods of low river stage, alluvial ground water discharges to the Colorado River. Ground water levels generally fluctuate between 2 to $5 \mathrm{ft}$ annually. Figures 3.5 and 3.6 are contour maps of the water table for the alluvial aquifer and potentiometric surface of the Wasatch Formation for the Old and New Rifle sites. The maps show little apparent variation in horizontal hydraulic gradient across the site. Horizontal ground water flow directions and gradients are particularly well documented near the New Rifle tailings. DOE has installed and has monitored ground water levels within a network of seven New Rifle alluvial well points from 1989 to present (Figure 3.6). Northernmost well points are situated between the New Rifle tailings and many of the private wells and springs to the north. Measurements are collected biweekly; the data indicate a relatively constant horizontal hydraulic gradient toward the southwest in the immediate vicinity of the New Rifle tailings regardless of the stage of the Colorado River. Ground water levels measured by DOE in New Rifle Wasatch monitor wells along profile A-A' (Figure 3.4) also show that ground water flows southwest and that ground water from upgradient Wasatch Formation beds recharge the alluvium along the northern boundary of the New Rifle site. All available water level data indicate there is no potential for ground water flow from the New Rifle processing site toward private wells and springs north of Highway 6 or toward private wells to the east.

In general, there are small to no downward vertical gradients at the Rifle sites from the alluvial aquifer to the upper weathered Wasatch Formation because they are hydraulically connected. Ground water levels from several Wasatch Formation well clusters at the New Rifle site indicate the vertical gradients deeper in the Wasatch Formation are complex. For example, New Rifle Wasatch monitor wells RFO-01-0640 and -0641 (Figure 3.4) are very near each other yet ground water levels measured in well RFO-01-0641 are consistently about $10 \mathrm{ft}$ higher. Well RFO-01-0641 is $86.5 \mathrm{ft}$ deep and is screened from approximately 70 to $80 \mathrm{ft}$. Well RFO-01-0640 is $160 \mathrm{ft}$ deep and screened from about 131 to $151 \mathrm{ft}$. The elevated ground water levels observed in well RFO-01-0641 are probably a result of water flowing downdip to the southwest along shale bedding of a lower hydraulic conductivity. The occurrence of springs along Wasatch bluffs in the vicinity of these wells supports this hypothesis. Further south, downgradient from the New Rifle tailings site, ground water levels from 


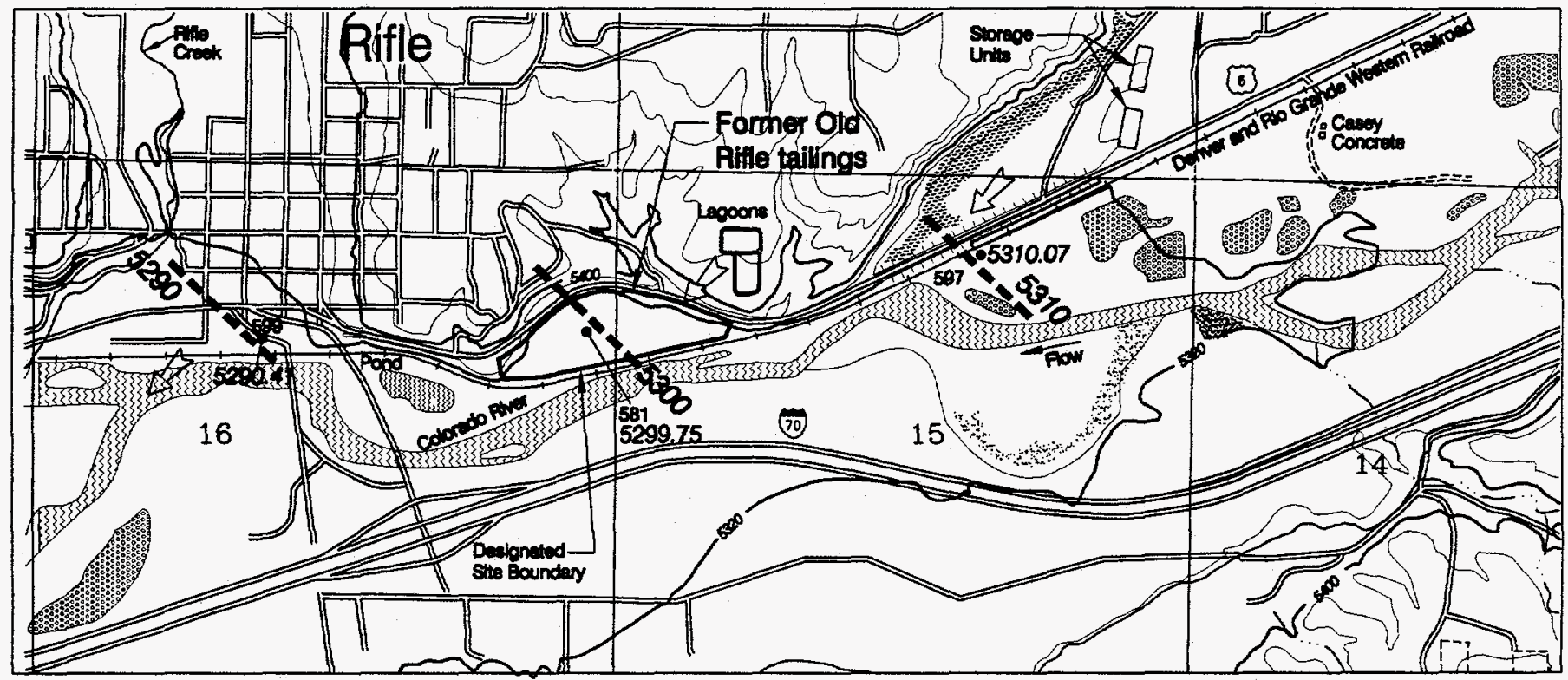

FIGURE 3.5a

WATER TABLE CONTOUR MAP OF THE ALLUVIAL AQUIFER OLD RIFLE, COLORADO, PROCESSING SITE VICINITY
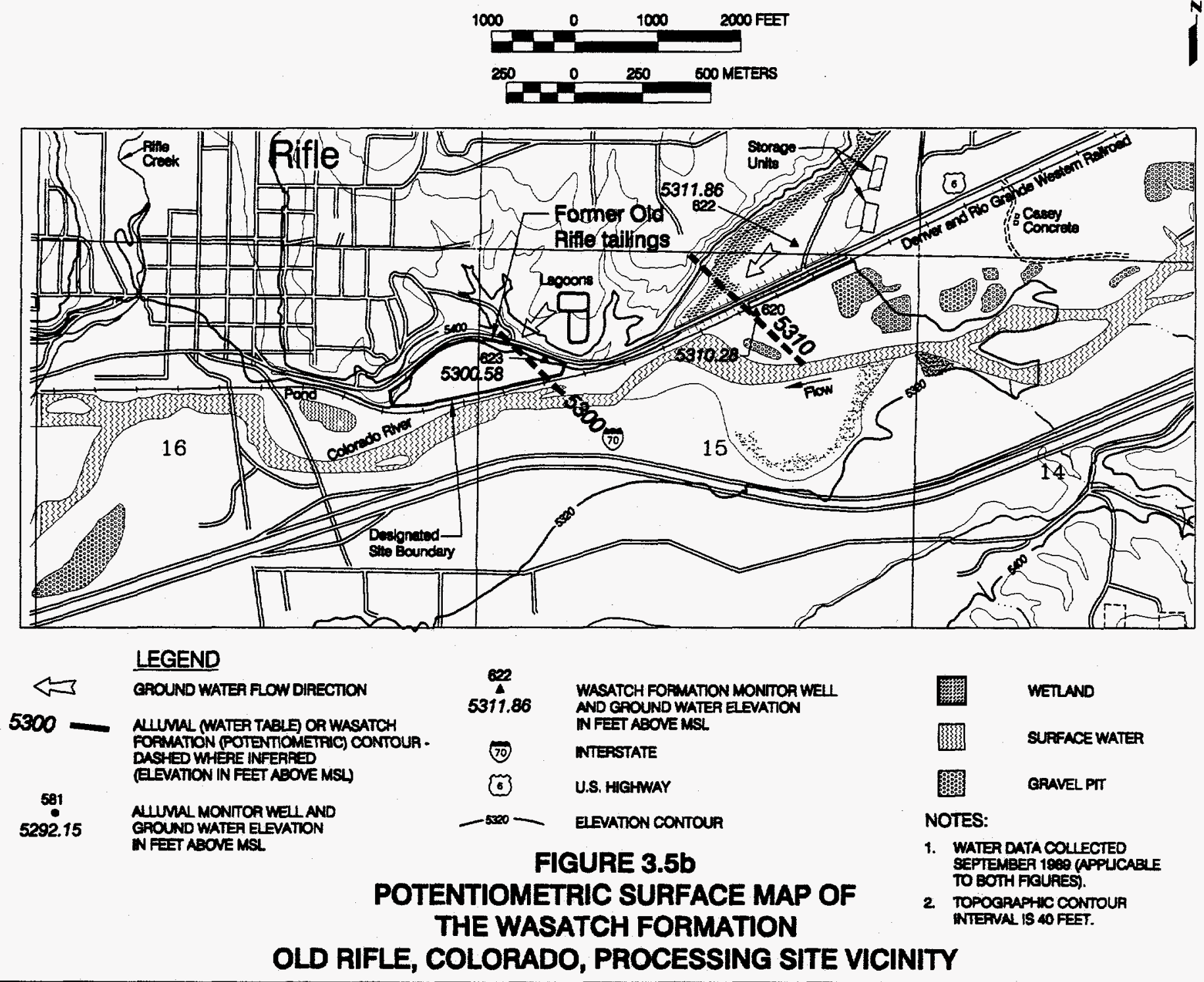

PC: $H$ : \USER \SSUNIGA \RFL \POSTRAP\SEPWTBOR.DWG (XREF-DR-2000.DWG) 4-25-95 


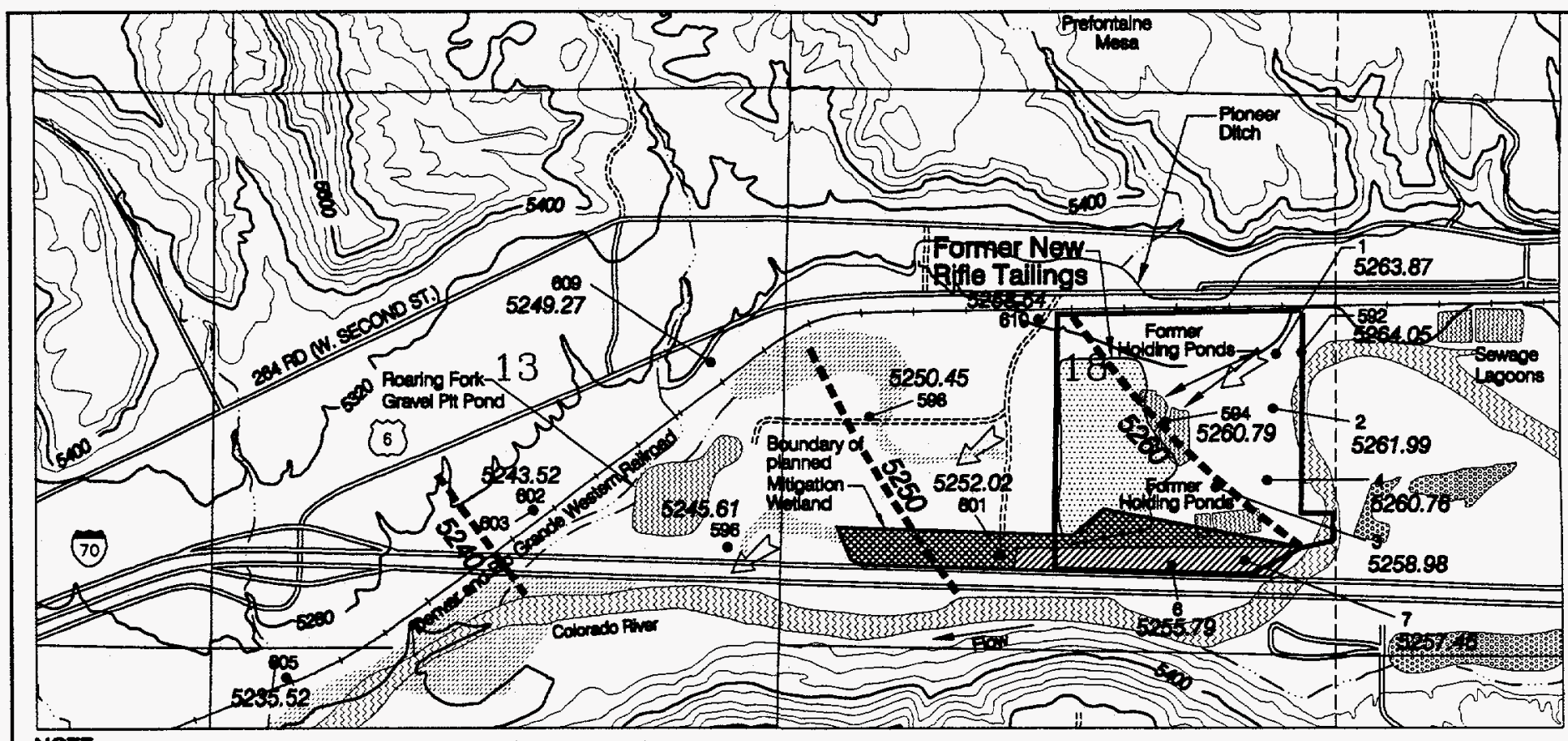

NOTE:

1. WELS $1,2,3,4,6$ AND 7

ARE MK WEL POINTS

FIGURE 3.6a

WATER TABLE CONTOUR MAP OF THE ALLUVIAL AQUIFER
NEW RIFLE, COLORADO, PROCESSING SITE VICINITY

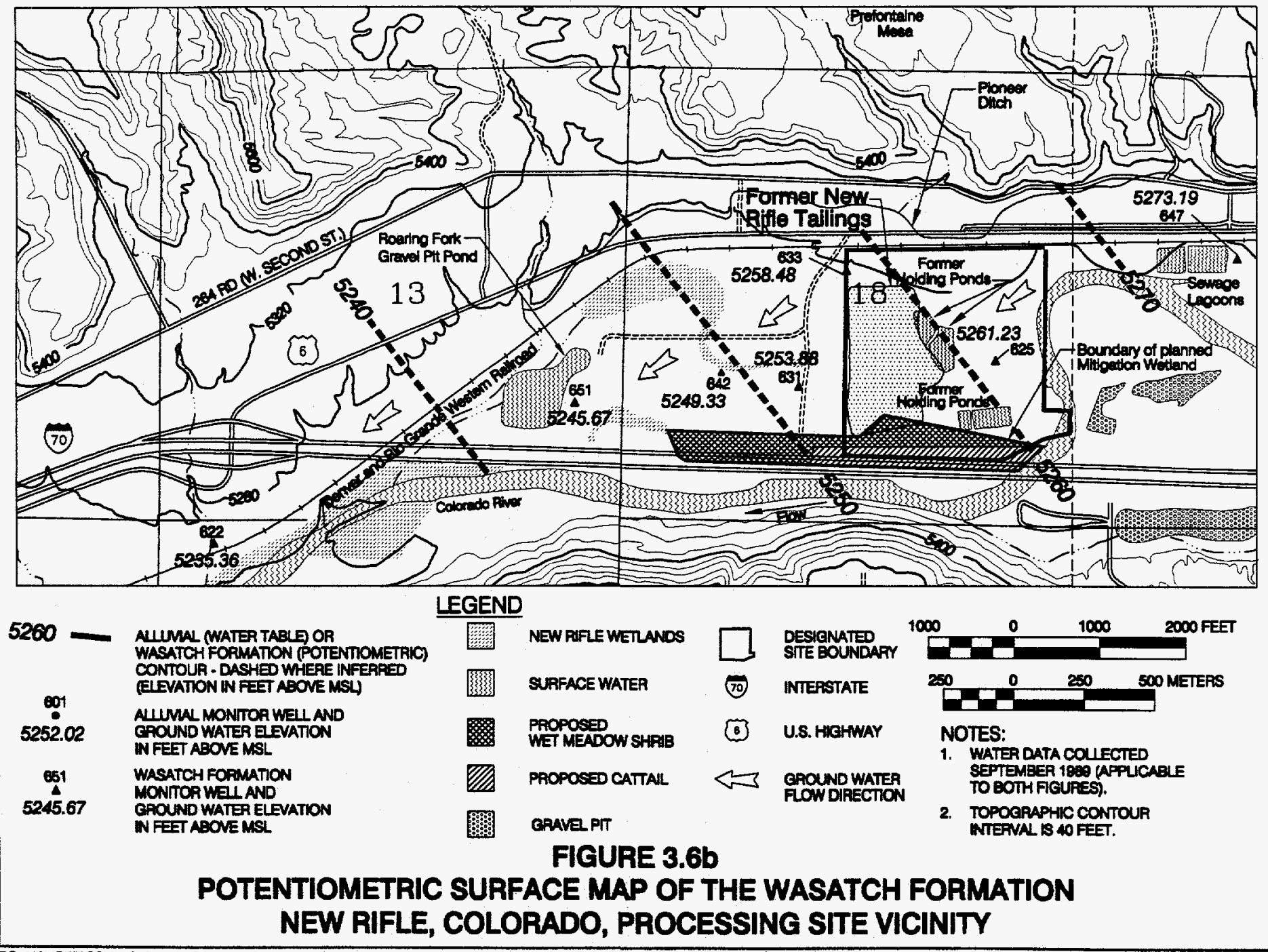


Wasatch Formation well cluster RFO-01-0642 and -0643 (completed at depths of 105 and $71 \mathrm{ft}$, respectively) show a reverse relationship. In this case, the deeper well (RFO-01-0642) consistently shows a ground water elevation approximately $50 \mathrm{ft}$ higher than in shallower well RFO-01-0643. Ground water level measurements from well RFO-01-0642 are consistent with levels from most other Wasatch wells; therefore, well RFO-01-0642 is believed to exhibit the dominant potentiometric surface of the Wasatch Formation near New Rifle. Well RFO-01-0643 may be completed in an aquitard. Water quality results and water levels from well RFO-01-0643 indicate there is a low degree of hydraulic connection with surrounding beds of the Wasatch Formation. Water levels observed in well RFO-01-0626 (screened from 66 to $76 \mathrm{ft}$ ) just east of the former New Rifle pile also indicate a much lower potentiometric surface when compared to nearby Wasatch wells. This supports the presence of an aquitard or separate flow system at a relatively shallow depth across the site. Further downgradient of the New Rifle tailings, wells RFO-01-0650 and -0651 (completed at 102 and $65 \mathrm{ft}$, respectively) each respond similarly to fluctuations in ground water levels.

Analysis of ground water level trends and ground water quality data indicate that there are at least four flow systems present near the new Rifle site. The upper flow system (north of the site) consists predominantly of springs that discharge along Wasatch Formation bedding surfaces. The second system (onsite), is the alluvial aquifer/upper Wasatch Formation system. The third is a lowpermeability aquitard across which wells RFO-01-0626 and -0643 are screened. The fourth consists of deeper, semiconfined sandstones and shales. The flow systems in the vicinity of the Rifle sites will be further defined in the site observational work plan.

At the Rifle sites, hydraulic conductivities range from 70 to $200 \mathrm{ft}$ per day in the alluvium and from 0.02 to $0.09 \mathrm{ft}$ per day in the Wasatch Formation. Average linear ground water velocities range from 280 to $840 \mathrm{ft}$ per year in the alluvium and from 0.3 to $3.0 \mathrm{ft}$ per year in the Wasatch Formation. Due to the limited nature of the test data, the heterogeneous nature of alluvial deposits, and the sensitivity of this term to various parameters, actual linear groundwater flow velocities at both the Old and New Rifle sites may vary considerably. This range in hydraulic conductivity will be defined further in the site observational work plan.

Because private wells completed north of Highway 6 are completed in Wasatch colluvium or beds of the Wasatch Formation, hydraulic conductivities are expected to be low in the vicinity of these wells. Analysis of historical water levels at the New Rifle site shows no apparent gradient changes from pumping domestic wells. Furthermore, gradient changes would not be expected because domestic wells north of Highway 6 are completed in entirely different hydrostratigraphic zones.

Less than $500 \mathrm{ft}$ southwest of the Old Rifle site, within the narrow floodplain between the Colorado River and the Old Rifle site, an outcrop of Wasatch 
bedrock slows ground water flow and diverts it toward the river. Although ground water flow is impeded downgradient of Old Rifle, a narrow deposit of alluvial material remains that could transmit ground water westward when it is saturated during high river stage events. Ground water migrating west of the Old Rifle site in the alluvial aquifer eventually would discharge to the Old Rifle pond or to the Colorado River $1500 \mathrm{ft}$ downgradient, where it bends approximately 90 degrees to the north. 


\subsection{NATURE AND EXTENT OF CONTAMINATION}

\subsection{BACKGROUND WATER QUALITY}

Background water quality is defined as the quality of ground water that would exist if uranium milling activities had not occurred. The Old Rifle and New Rifle sites are less than 2 miles apart and ground water occurs within the same geologic units at both sites. Thus, the same background wells can be used to define background ground water quality conditions for both sites. DOE monitor wells selected to describe background ground water quality conditions at the sites for purposes of the recent baseline risk assessment showed concentrations of some parameters that exceed U.S. Environmental Protection Agency (EPA) maximum concentration limits (MCL). Consequently, in addition to describing local background ground water quality in DOE monitor wells, regional ground water quality data are discussed below to account for certain constituents that occur at relatively high background levels.

Understanding of background water quality for the Rifle sites has been refined as a result of baseline risk assessment activities. In the recent baseline risk assessment, background for the sites was described separately for the alluvial aquifer and the Wasatch Formation. This position paper focuses on private water supplies completed in alluvial and Wasatch hydrostratigraphic environments that may be slightly different from what exists at the sites. To provide a transition from the recent baseline risk assessment to this position paper, background is described separately for the alluvial aquifer and Wasatch Formation at the processing sites. Then an alternative definition of background water quality is presented that is more appropriate for the private water supplies located north or east of the New Rifle site.

\subsubsection{Alluvial background water}

Background water quality data for conditions in the alluvium at both old and New Rifle are available from Old Rifle upgradient monitor wells RF0-01-0597, $-0598,-0605$, and -0606 (Figure 2.1). These wells are at least 0.5 miles upgradient of the Old Rifle site and are not affected by uranium milling activities. Because ground water in monitor wells RFO-01-0597 and -0598 was at one time believed to have potentially been affected by uranium processing activities (DOE, 1992b), monitor wells RFO-01-0605 and -0606 were recently installed upgradient of the gravel pit. Three rounds of data from monitor well RFO-01-0605 and two rounds from -0606 are consistent with data from monitor wells RFO-01-0597 and -0598 , confirming that water quality in wells RFO-01-0597 and -0598 represents background water quality in the alluvial aquifer.

The dominant anionic species in the alluvial background water is sulfate. This water has a mixed sodium-calcium-magnesium-cation composition with a tendency for sodium to dominate. Most trace elements were detected at low 
concentrations or were never detected in analyses of background alluvial ground water. Molybdenum, selenium, and uranium are exceptions. Historical concentrations of these constituents in alluvial background ground water have been as high as 0.036 (molybdenum), 0.19 (selenium), and 0.046 (uranium) $\mathrm{mg} / \mathrm{L}$. These selenium and uranium values are above EPA MCLs. In addition, net gross alpha values as high as 56 picocuries per liter $(\mathrm{pCi} / \mathrm{L})$ and nitrate values as high as $7.8 \mathrm{mg} / \mathrm{L}$ have been observed.

\subsubsection{Wasatch background water}

Background water quality data for conditions in the Wasatch Formation at both Old and New Rifle are available from Old Rifle monitor wells RFO-01-0620, -0621 , and -0622 and New Rifle monitor wells RF0-01-0640 and -0641 (Figure 2.1). Monitor wells RFN-01-0621/-0622 and -0640/-0641 represent paired Wasatch Formation wells, with one pair upgradient of each site. One well in each pair screens ground water just below the Wasatch/alluvium contact and one well samples ground water from deeper in the Wasatch Formation. Monitor well RFO-01-0620 is near the RFN-01-0621/-0622 pair but is screened at a shallower depth, representing water directly below the Wasatch/alluvium contact.

The dominant anion species in the Wasatch Formation background water is chloride in all wells except monitor well RFO-01-0641, which is higher in sulfate. Sodium is the dominant cation in all Wasatch Formation background wells. Concentrations of molybdenum, selenium, and uranium are noteworthy in Wasatch Formation background water, just as they are in alluvial background water. Their occurrence is expected as ground water from the upgradient Wasatch Formation discharges to the alluvium along the northern borders of the Rifle sites. Historical concentrations of these constituents in Wasatch Formation background ground water are as high as 0.12 (molybdenum), 0.34 (selenium), and 0.057 (uranium) $\mathrm{mg} / \mathrm{L}$. These values are all above Uranium Mill Tailings Remedial Action (UMTRA) Project MCLs.

\subsubsection{Background for private water sources north or east of New Rifle}

As discussed in Sections 2 and 3, the private water sources located north or east of the New Rifle site generally access water from a higher flow system than exists at the processing sites. For this reason, upgradient private spring RFO-01-0573 and upgradient private well RF0-01-0436 are used in this position paper to quantify background water quality for comparison to RFN-01-0421 through $-0427,-0430$ through -0433 , and -0435 . These two upgradient locations access water from similar hydrostratigraphic units as the private water sources listed above but are sufficiently upgradient of both processing sites to ensure they have not been impacted by uranium milling activities.

Upgradient spring RFO-01-0573 represents water from the Wasatch colluvium and upper Wasatch (Figure 2.1). The colluvium overlies an escarpment of Wasatch Formation that rises nearly $100 \mathrm{ft}$ above the top of the Old Rifle 
tailings pile approximately 1 mile northeast of the Old Rifle site. Water quality analyses from this location show uranium concentrations up to $0.048 \mathrm{mg} / \mathrm{L}$, net gross alpha up to $33 \mathrm{pCi} / \mathrm{L}$, and total sulfate concentrations up to $2010 \mathrm{mg} / \mathrm{L}$.

Upgradient private well RFO-01-0436 represents water quality in the alluvial Wasatch interface and the upper Wasatch Formation. Ground water sampled from -0436 contains concentrations of uranium, sulfate and additional constituents with a similar range as in samples from -0573 .

\subsubsection{Comparison with regional background water}

Markos and Bush (1983) sampled and analyzed ground water in five wells in the Rifle area, all away from the possible influence of uranium mill-related activities. These data are from an area of about $\mathbf{5 0}$ square miles surrounding Rifle. Ground water quality in the background wells is similar to regional water quality in several respects. For example, regional sulfate ranges from 68 to near $1000 \mathrm{mg} / \mathrm{L}$ and uranium ranges from 0.002 to $0.067 \mathrm{mg} / \mathrm{L}$. These ranges are similar to background wells.

More evidence of the regional distribution of uranium and associated metals and radionuclides is seen in ground water sampled at Estes Gulch, Colorado. Ground water sampled from wells completed in the Wasatch Formation prior to tailings disposal at the Estes Gulch site 6.2 mile north of the Rifle processing sites contained measurable levels of barium, uranium, selenium, lead, chromium, vanadium, net gross alpha, and radium. Selenium concentrations in ground water at Estes Gulch range from 0.022 to $0.975 \mathrm{mg} / \mathrm{L}$, and the average selenium concentration was found to be 15 times greater than the EPA MCL of $0.01 \mathrm{mg} / \mathrm{L}$. Barium, cadmium, lead, molybdenum, net gross alpha, and radium-226 and -228 combined have also exceeded the EPA MCLs in ground water samples collected at Estes Gulch (DOE, 1992). Many of these constituents, particularly molybdenum and selenium, are commonly associated with uranium deposits (Evans, 1987); their presence in association with uranium in background is expected.

The above discussion indicates that several constituents associated with uranium ores are naturally present in regional ground water. This is likely because the regional ground water recharge area contains known uranium ore bodies and because the Wasatch Formation is partially derived from surrounding uplifted formations that contain uranium and associated metals. Other unknown uranium ore bodies may be present.

\subsection{NATURE AND EXTENT OF SITE-RELATED CONTAMINATION}

Figures 4.1, 4.2, and 4.3 show the current uranium distribution in the alluvium at the Old Rifle site and in the alluvium and the Wasatch Formation at the New Rifle site, respectively. There are not enough well locations in the Wasatch

Formation at the Old Rifle site to fully characterize the distribution of 


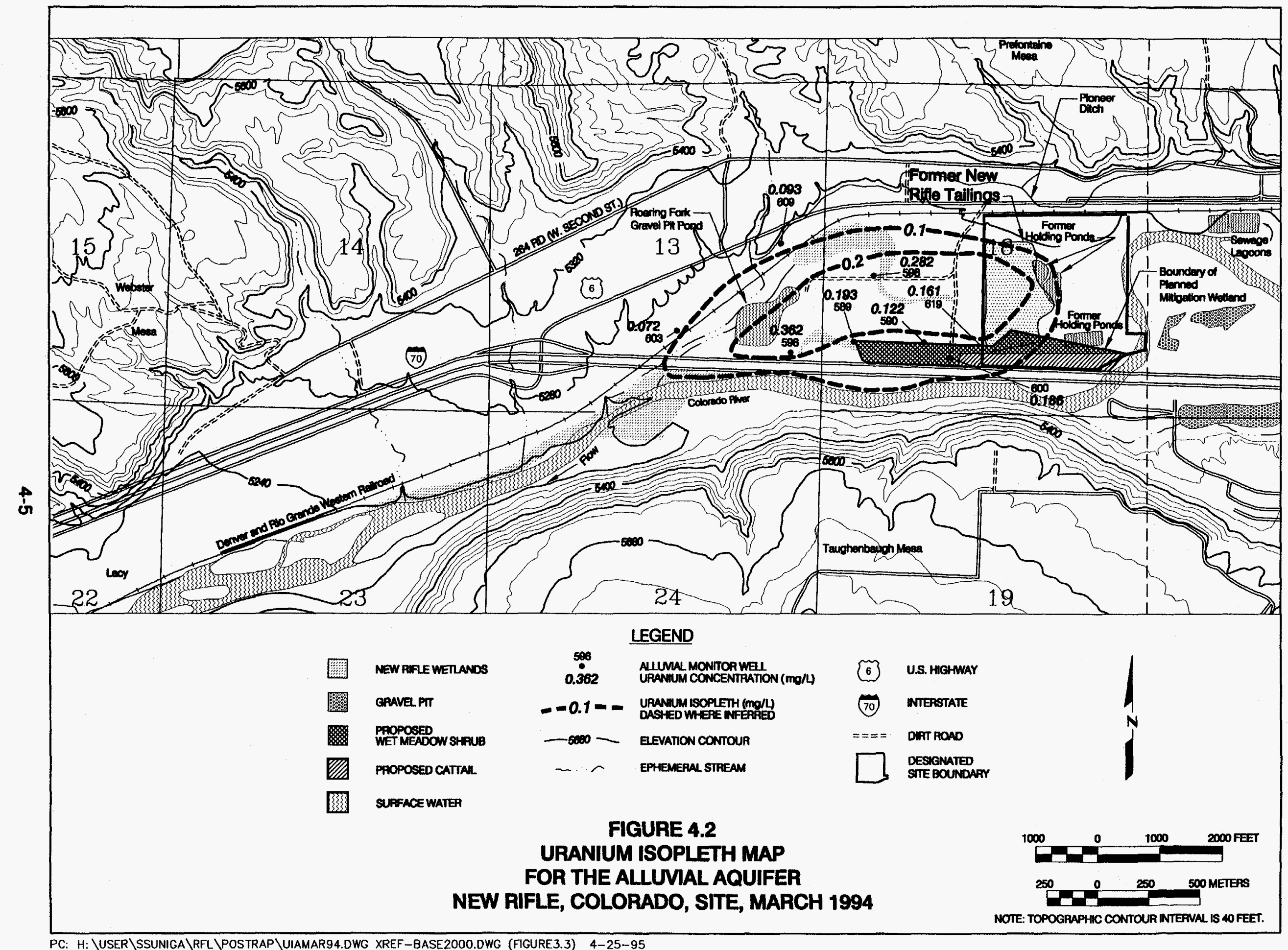

PC: H: \USER \SSUNIGA \RFL \POSTRAP \UIAMAR94.DWG XREF-BASE2000.DWG (FIGURE3.3) 4-25-95 


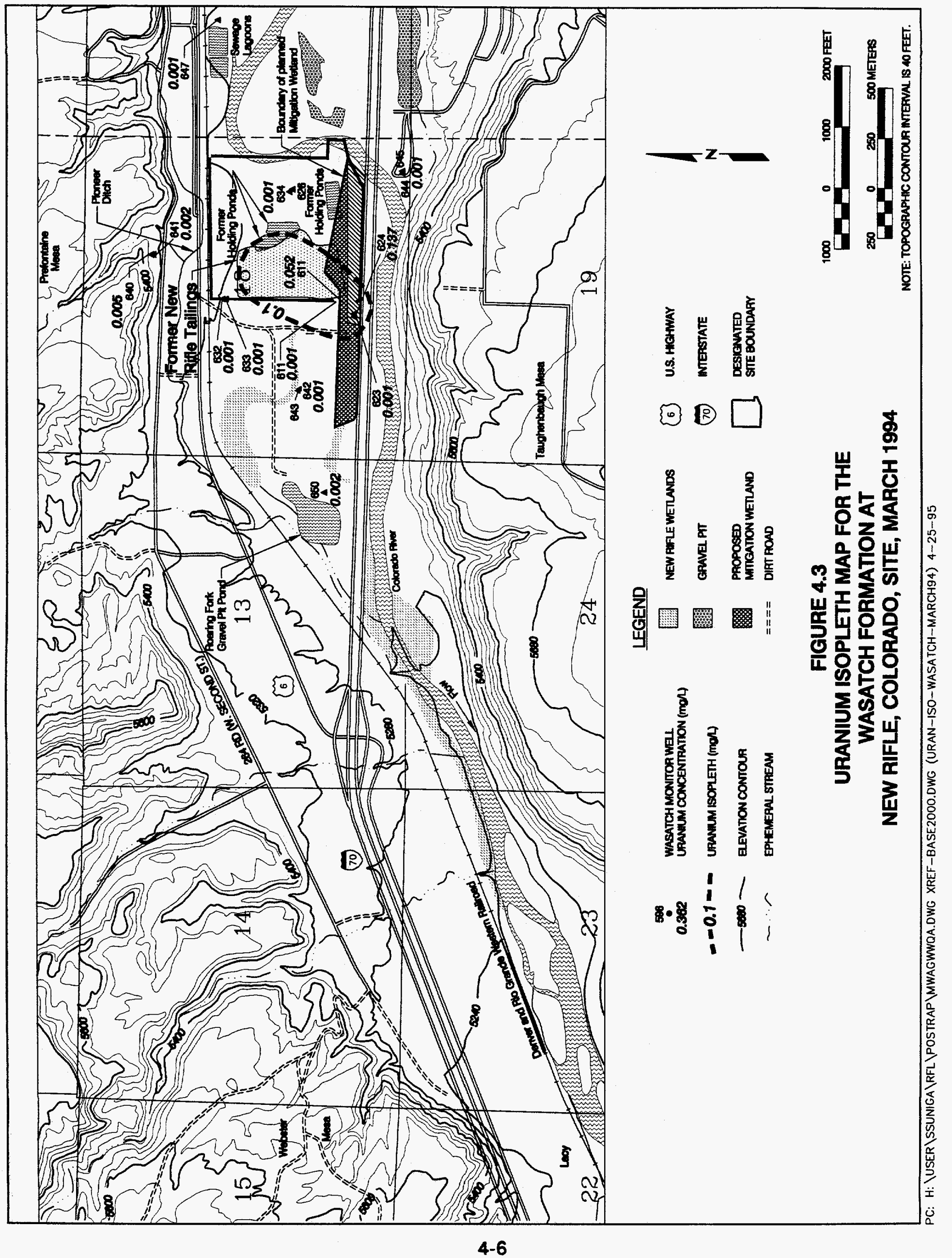


contamination. However, contamination at both sites is less extensive in the Wasatch Formation than in the alluvium. Contamination in the Wasatch Formation does not appear to have moved far from the tailings pile (compare Figures 4.2 and 4.3). This is consistent with the lower permeability of the Wasatch Formation.

At Old Rifle, the alluvium is bounded on the north by an escarpment of the Wasatch Formation and on the south by the Colorado River (Figure 5.1) with ground water flowing southwest in the alluvium, parallel to the river at times of high river stages. The Wasatch Formation escarpment extending toward the river funnels the bulk of alluvial ground water flow into the Colorado River. Thus, most contamination is confined to the processing and tailings site itself. Downgradient DOE well RFO-01-0604, located near private well RFN-01-0421 (Figure 2.1), has never indicated above-background levels of site-related contaminants.

At New Rifle, as at Old Rifle, the alluvium pinches out against an escarpment of Wasatch Formation directly north of the site. The escarpment of Wasatch Formation north of the New Rifle site is approximated by the 5280-ft elevation contour on Figure 4.2. Therefore, ground water flow in the alluvium is effectively limited to the area between the escarpment of Wasatch Formation north of the site and the Colorado River south of the site with ground water flowing west, parallel to the river. Thus, contamination is elongated southwest from the site, in the general direction of ground water flow (Figure 4.2).

\subsubsection{Possible site contamination of private well RFN-01-0428}

At New Rifle, elevated levels of certain constituents in far downgradient monitor well RFN-01-0620 (Figure 2.1) suggest that uranium processing-related contamination may have traveled as much as 3 miles in the direction of ground water flow. Concentrations of calcium, chloride, magnesium, nitrate, sodium, and sulfate show increasing trends over time in monitor well RFN-01-0620. Sodium and sulfate, however, are the primary constituents that are elevated above background with levels up to 1300 and $2900 \mathrm{mg} / \mathrm{L}$, respectively. Uranium, another primary indicator of contamination from uranium milling activities, is only slightly elevated above background. Similar water occurs in a natural seep (Old Rifle surface location RFO-01-0573), demonstrating that a natural source is possible for ground water in DOE monitor well RFN-01-0620 and private well RFN-01-0428.

There may be other explanations for observed constituent levels in these wells. Monitor well RFN-01-0620 and nearby private well RFN-01-0428 probably receive ground water from a recharge area to the north that includes large exposures of the Green River Formation. The Green River Formation is notable for the occurrence of a variety of unusual sodium salts (Greensmith et al., 1971). Thus, high levels of sodium and sulfate could be coming from this alternate source. Also, well RFN-01-0620 is in an irrigated field with white salts crusted on the surface. These salts likely are sodium-sulfate salts from the 
evaporation of sodium-sulfate water (the dominant ground water type in the alluvial aquifer). A light rain would dissolve these salts, elevating sodium and sulfate in nearby ground water. Nitrate is commonly used to fertilize crops. Thus, observed levels of these constituents could reasonably have come from sources other than uranium milling-related activities.

Because of these uncertainties, the data are insufficient to state conclusively whether elevated levels of constituents observed in monitor well RFN-01-0620 (and in private well RFN-01-0428) are related to uranium processing. It is possible to say, however, that the high concentrations of constituents observed just downgradient of the New Rifle tailings pile would be subject to large dispersion and dilution effects in the 2.5- to 3-mi travel that is required to reach wells RFN-01-0428 and RFN-01-0620. If a slug of contamination from the UMTRA site could reach these wells, the size of the slug would expand to the southwest due to dispersion and much of it would be forced into the Colorado River where the effect would not be measurable. Additionally, many contaminants are retarded or naturally attenuated by precipitation or adsorption onto the aquifer matrix. Thus, concentrations that actually reached wells RFN01-0428 and RFN-01-0620 would be a fraction of the initial concentrations. 


\subsection{STATISTICAL COMPARISON OF BACKGROUND WATER QUALITY WITH PRIVATE WATER QUALITY NORTH TO EAST OF SITE}

The recent Rifle baseline risk assessment identified 24 inorganic constituents that are elevated above background in the shallow groundwater under the New Rifle site. In addition, the baseline risk assessment evaluates the potential carcinogenicity of several radioactive decay products of natural uranium. Table 5.1 presents a summary of the concentration levels for these 24 inorganic constituents and monitored radionuclides measured in 5 different groups of wells and springs in the vicinity of Rifle.

The first two groups represent the DOE monitor locations used in the recent baseline risk assessment to quantify background water quality at the sites in the alluvial aquifer (RFO01-0597, -0598, -0605, -0606) and the Wasatch aquifer (RF0-01-0620, -0622, and RFN01-0641). The third group are the two background water locations, RFO-01-0436 and -0573, that represent water quality in the shallow Wasatch and alluvial/Wasatch interface. As discussed in Section 4.1.3, these locations are clearly upgradient of both the New and Old Rifle site are believed to be representative of the flow system most likely affecting the group of private water sources north or east of the New Rifle site. The 12 upgradient and crossgradient private water locations north or east of New Rifle (RFN-01-0421 through $-0427,-0430$ through -0433 , and -0435 ) constitute the fourth group, and downgradient private well RFN-428 forms its own group. Data from private well RFN-01-0560 were not included because the location and depth of this well protects it from site contamination (Section 3.5). Data from private well RFN-01-0559 were excluded because only one round of sampling took place at this location prior to decommissioning of the well.

Table 5.1 covers the same time period used in the recent baseline risk assessment plus one additional round of sampling that took place at the Rifle site on December, 1994. Water samples collected from wells in the DOE monitor well groups are filtered prior to chemical analysis, whereas the data from private wells and springs represent unfiltered water quality. The DOE typically collects unfiltered water samples from private wells that are pumped regularly, whereas filtration is standard procedure for monitor wells.

Table 5.1 illustrates differences in background water quality that were discussed in the previous section and shows that the aggregated upgradient and crossgradient private water quality data fall within the range of one or more of the background groups. However, variation between wells within the same group cannot be seen in the Table. Therefore, individual well differences in concentrations of sulfate, uranium, molybdenum, and radium ( $226+228$ combined) are presented in Figures 5.1 through 5.4 in the form of boxplots. A boxplot summarizes several features of a data set: the smallest value, the 25 th percentile, 50th percentile, 75 th percentile and the largest value. The boxplots show significant variation in background water quality that correlates with the various flow systems known to be present in the vicinity of the site. The upgradient and crossgradient private water locations vary among themselves to a lesser degree, but none can clearly be distinguished from background. The graphs also demonstrate that downgradient private well RFN-428 has higher concentrations of sulfate and uranium than have been measured in any of the background wells or springs at the site. 
Table 5.1 Summary of water quality for background and private water locations, Rifle, Colorado, sites (08/90 - 12/94)

\begin{tabular}{|c|c|c|c|c|c|}
\hline \multirow[b]{2}{*}{ Constituent } & \multirow[b]{2}{*}{ Well groups ${ }^{\circ}$} & \multirow{2}{*}{$\begin{array}{c}\text { Frequency of } \\
\text { detection }\end{array}$} & Minimum & Median" & Maximum \\
\hline & & & \multicolumn{3}{|c|}{ (mg/L) } \\
\hline \multicolumn{6}{|l|}{ Inorganics } \\
\hline \multirow[t]{5}{*}{ Ammonium } & Alluvial background & $9 / 14$ & $<0.1$ & 0.5 & 1.5 \\
\hline & Wasatch background & $11 / 14$ & $<0.1$ & 0.6 & 2.7 \\
\hline & Private well/spring background & $2 / 5$ & $<0.1$ & $<0.1$ & 0.8 \\
\hline & $\begin{array}{l}\text { Upgradient/crossgradient } \\
\text { private well/spring }\end{array}$ & $30 / 49$ & $<0.1$ & 0.2 & 1.7 \\
\hline & Downgradient & $2 / 10$ & $<0.1$ & 0.1 & 0.7 \\
\hline \multirow[t]{5}{*}{ Antimony ${ }^{\circ}$} & Alluvial background & $0 / 5$ & $<0.003$ & $<0.003$ & $<0.003$ \\
\hline & Wasatch background & $0 / 10$ & $<0.003$ & $<0.003$ & $<0.03$ \\
\hline & Private well/spring background & $1 / 3$ & $<0.003$ & $<0.003$ & 0.004 \\
\hline & $\begin{array}{l}\text { Upgradient/crossgradient } \\
\text { private well/spring }\end{array}$ & $4 / 51$ & $<0.003$ & $<0.003$ & 0.01 \\
\hline & Downgradient & $1 / 5$ & $<0.003$ & $<0.003$ & $0.01^{\dagger}$ \\
\hline \multirow[t]{5}{*}{ Arsenic $^{\circ}$} & Alluvial background & $2 / 13$ & $0.001^{f}$ & $<0.005$ & $<0.01$ \\
\hline & Wasatch background & $4 / 10$ & 0.001 & $<0.005$ & $0.008^{f}$ \\
\hline & Private well/spring background & $2 / 4$ & $<0.005$ & $<0.006$ & 0.024 \\
\hline & $\begin{array}{l}\text { Upgradient/crossgradient } \\
\text { private well/spring }\end{array}$ & $18 / 64$ & $<0.001$ & $<0.005$ & 0.022 \\
\hline & Downgradient & $1 / 8$ & $<0.001$ & $<0.005$ & $0.007^{f}$ \\
\hline \multirow[t]{5}{*}{ Cadmium } & Alluvial background & $0 / 9$ & $<0.001$ & $<0.001$ & $<0.001$ \\
\hline & Wasatch background & $1 / 13$ & $<0.0005$ & $<0.001$ & 0.003 \\
\hline & Private well/spring background & $1 / 4$ & $<0.0005$ & $<0.001$ & 0.026 \\
\hline & $\begin{array}{l}\text { Upgradient/crossgradient } \\
\text { private well/spring }\end{array}$ & $5 / 68$ & $<0.0005$ & $<0.001$ & $0.006^{f}$ \\
\hline & Downgradient & $1 / 12$ & $<0.0005$ & $<0.001$ & $0.003^{f}$ \\
\hline \multirow[t]{5}{*}{ Calcium } & Alluvial background & $17 / 17$ & 81 & 157 & 229 \\
\hline & Wasatch background & $15 / 15$ & 3.6 & 17 & 319 \\
\hline & Private well/spring background & $6 / 6$ & 114 & 131 & 255 \\
\hline & $\begin{array}{l}\text { Upgradient/crossgradient } \\
\text { private well/spring }\end{array}$ & $59 / 59$ & 4.5 & 124 & 243 \\
\hline & Downgradient & $11 / 11$ & 310 & 326 & 374 \\
\hline
\end{tabular}


Table 5.1 Summary of water quality for background and private water locations, Rifle, Colorado, sites (08/90 - 12/94) (Continued)

\begin{tabular}{|c|c|c|c|c|c|}
\hline \multirow[b]{2}{*}{ Constituent ${ }^{\mathbf{b}}$} & \multirow[b]{2}{*}{ Well groups" } & \multirow{2}{*}{$\begin{array}{c}\text { Frequency of } \\
\text { detection }\end{array}$} & Minimum & Median" & Maximum \\
\hline & & & \multicolumn{3}{|c|}{$(\mathbf{m g} / \mathrm{L})$} \\
\hline \multirow[t]{5}{*}{ Chloride } & Alluvial background & $15 / 15$ & 62 & 95 & 261 \\
\hline & Wasatch background & $14 / 14$ & 165 & 523 & 622 \\
\hline & Private well/spring background & $6 / 6$ & 44 & 196 & 213 \\
\hline & $\begin{array}{l}\text { Upgradient/crossgradient } \\
\text { private well/spring }\end{array}$ & $59 / 59$ & 11 & 34 & 486 \\
\hline & Downgradient & $11 / 11$ & 411 & 445 & 606 \\
\hline \multirow[t]{5}{*}{ Cobalt } & Alluvial background & $0 / 2$ & $<0.01$ & $<0.01$ & $<0.01$ \\
\hline & Wasatch background & $0 / 6$ & $<0.01$ & $<0.02$ & $<0.03$ \\
\hline & Private well/spring background & $0 / 3$ & $<0.01$ & $<0.03$ & $<0.03$ \\
\hline & $\begin{array}{l}\text { Upgradient/crossgradient } \\
\text { private well/spring }\end{array}$ & $0 / 32$ & $<0.01$ & $<0.0$ & $<0.05$ \\
\hline & Downgradient & $0 / 4$ & $<0.01$ & $<0.03$ & $<0.05$ \\
\hline \multirow[t]{5}{*}{ Fluoride } & Alluvial background & $15 / 15$ & 0.40 & 0.50 & 1.2 \\
\hline & Wasatch background & $14 / 14$ & 0.18 & 2.4 & 4.5 \\
\hline & Private well/spring background & $6 / 6$ & 0.40 & 0.98 & 1.4 \\
\hline & $\begin{array}{l}\text { Upgradient/crossgradient } \\
\text { private well/spring }\end{array}$ & $68 / 68$ & 0.40 & 0.66 & 2.6 \\
\hline & Downgradient & $12 / 12$ & 0.29 & 0.31 & 0.5 \\
\hline \multirow[t]{5}{*}{ Iron } & Alluvial background & $16 / 17$ & $<0.03$ & 1.0 & 2.4 \\
\hline & Wasatch background & $7 / 15$ & $<0.02$ & $<0.03$ & 0.24 \\
\hline & Private well/spring background & $6 / 6$ & 0.03 & 0.06 & 0.17 \\
\hline & $\begin{array}{l}\text { Upgradient/crossgradient } \\
\text { private well/spring }\end{array}$ & $67 / 68$ & $<0.03$ & 0.24 & 12 \\
\hline & Downgradient & $12 / 12$ & 0.19 & 0.54 & 2.6 \\
\hline \multirow[t]{5}{*}{ Lead $^{\circ}$} & Alluvial background & $1 / 5$ & $<0.001$ & $0.007^{f}$ & $<0.01$ \\
\hline & Wasatch background & $1 / 9$ & $0.001^{\dagger}$ & $<0.005$ & $<0.01$ \\
\hline & Private well/spring background & $0 / 2$ & $<0.001$ & $<0.002$ & $<0.003$ \\
\hline & $\begin{array}{l}\text { Upgradient/crossgradient } \\
\text { private well/spring }\end{array}$ & $15 / 49$ & $<0.001$ & $<0.005$ & 0.017 \\
\hline & Downgradient & $2 / 5$ & $<0.001$ & $<0.005$ & $0.006^{\dagger}$ \\
\hline
\end{tabular}


Table 5.1 Summary of water quality for background and private water locations, Rifle, Colorado, sites (08/90 - 12/94) (Continued)

\begin{tabular}{|c|c|c|c|c|c|}
\hline \multirow[b]{2}{*}{ Constituent } & \multirow[b]{2}{*}{ Well groups ${ }^{\circ}$} & \multirow{2}{*}{$\begin{array}{c}\text { Frequency of } \\
\text { detection }^{d}\end{array}$} & Minimum & Median" & Maximum \\
\hline & & & \multicolumn{3}{|c|}{ (mg/L) } \\
\hline \multirow[t]{5}{*}{ Manganese } & Alluvial background & $17 / 17$ & 0.10 & 2.8 & 4.2 \\
\hline & Wasatch background & $12 / 15$ & 0.01 & 0.06 & 1.0 \\
\hline & Private well/spring background & $5 / 6$ & $<0.01$ & 0.17 & 0.57 \\
\hline & $\begin{array}{l}\text { Upgradient/crossgradient } \\
\text { private well/spring }\end{array}$ & $49 / 68$ & $<0.01$ & 0.05 & 2.4 \\
\hline & Downgradient & $12 / 12$ & 0.12 & 0.22 & 0.30 \\
\hline \multirow[t]{5}{*}{ Molybdenum } & Alluvial background & $12 / 17$ & $<0.01$ & 0.03 & 0.06 \\
\hline & Wasatch background & $15 / 15$ & 0.01 & 0.20 & 0.30 \\
\hline & Private well/spring background & $5 / 6$ & $<0.01$ & 0.03 & 0.08 \\
\hline & $\begin{array}{l}\text { Upgradient/crossgradient } \\
\text { private well/spring }\end{array}$ & $40 / 68$ & $<0.01$ & 0.01 & 0.06 \\
\hline & Downgradient & $2 / 12$ & $<0.01$ & $<0.01$ & 0.07 \\
\hline \multirow[t]{5}{*}{ Nickel } & Alluvial background & $0 / 2$ & $<0.01$ & $<0.01$ & $<0.01$ \\
\hline & Wasatch background & $0 / 3$ & $<0.01$ & $<0.01$ & $<0.01$ \\
\hline & Private well/spring background & $0 / 1$ & $<0.01$ & $<0.01$ & $<0.01$ \\
\hline & $\begin{array}{l}\text { Upgradient/crossgradient } \\
\text { private well/spring }\end{array}$ & $1 / 34$ & $<0.01$ & $0.01^{\dagger}$ & $<0.04$ \\
\hline & Downgradient & $0 / 4$ & $<0.01$ & $<0.03$ & $<0.04$ \\
\hline \multirow[t]{5}{*}{ Nitrate } & Alluvial background & $5 / 12$ & $<0.1$ & $<1.0$ & 7.8 \\
\hline & Wasatch background & $7 / 16$ & $<0.1$ & $<1.0$ & 9.0 \\
\hline & Private well/spring background & $4 / 5$ & $<1.0$ & 6.5 & 7.0 \\
\hline & $\begin{array}{l}\text { Upgradient/crossgradient } \\
\text { private well/spring }\end{array}$ & $32 / 49$ & $<0.1$ & 1.8 & 17 \\
\hline & Downgradient & $10 / 10$ & 12 & 44 & 59 \\
\hline \multirow[t]{5}{*}{ Phosphate" } & Alluvial background & $1 / 5$ & $<0.1$ & $<0.1$ & 0.1 \\
\hline & Wasatch background & $4 / 7$ & $<0.1$ & 0.3 & 0.6 \\
\hline & Private well/spring background & $1 / 3$ & $<0.1$ & $<0.1$ & 0.1 \\
\hline & $\begin{array}{l}\text { Upgradient/crossgradient } \\
\text { private well/spring }\end{array}$ & $12 / 32$ & $<0.1$ & $<0.1$ & 1.0 \\
\hline & Downgradient & $2 / 3$ & $<0.1$ & 0.1 & 0.1 \\
\hline
\end{tabular}


Table 5.1 Summary of water quality for background and private water locations, Rifle, Colorado, sites (08/90 - 12/94) (Continued)

\begin{tabular}{|c|c|c|c|c|c|}
\hline \multirow[b]{2}{*}{ Constituent } & \multirow[b]{2}{*}{ Well groups $^{c}$} & \multirow{2}{*}{$\begin{array}{c}\text { Frequency of } \\
\text { detection }\end{array}$} & Minimum & Median" & Maximum \\
\hline & & & \multicolumn{3}{|c|}{ (mg/L) } \\
\hline \multirow[t]{5}{*}{ Potassium } & Alluvial background & $17 / 17$ & 3.2 & 5.1 & 13 \\
\hline & Wasatch background & $15 / 15$ & 1.6 & 5.5 & 6.7 \\
\hline & Private well/spring background & $6 / 6$ & 3.9 & 3.9 & 10 \\
\hline & $\begin{array}{l}\text { Upgradient/crossgradient } \\
\text { private well/spring }\end{array}$ & $54 / 54$ & 1.0 & 4.9 & 8.0 \\
\hline & Downgradient & $9 / 9$ & 5.1 & 6.5 & 7.4 \\
\hline \multirow[t]{5}{*}{ Selenium ${ }^{\bullet}$} & Alluvial background & $4 / 17$ & $<0.002$ & $<0.005$ & 0.013 \\
\hline & Wasatch background & $0 / 15$ & $<0.002$ & $<0.005$ & $<0.05$ \\
\hline & Private well/spring background & $3 / 5$ & $<0.005$ & 0.007 & 0.021 \\
\hline & $\begin{array}{l}\text { Upgradient/crossgradient } \\
\text { private well/spring }\end{array}$ & $35 / 61$ & $<0.002$ & 0.005 & 0.049 \\
\hline & Downgradient & $5 / 8$ & $<0.002$ & 0.006 & 0.009 \\
\hline \multirow[t]{5}{*}{ Silica } & Alluvial background & $15 / 15$ & 17 & 19 & 25 \\
\hline & Wasatch background & $14 / 14$ & 7.0 & 8.9 & 17 \\
\hline & Private well/spring background & $6 / 6$ & 5.8 & 25 & 32 \\
\hline & $\begin{array}{l}\text { Upgradient/crossgradient } \\
\text { private well/spring }\end{array}$ & $49 / 49$ & 6.6 & 19 & 50 \\
\hline & Downgradient & $10 / 10$ & 19 & 21 & 26 \\
\hline \multirow[t]{5}{*}{ Sodium } & Alluvial background & $17 / 17$ & 177 & 226 & 617 \\
\hline & Wasatch background & $15 / 15$ & 363 & 532 & 1030 \\
\hline & Private well/spring background & $6 / 6$ & 214 & 469 & 509 \\
\hline & $\begin{array}{l}\text { Upgradient/crossgradient } \\
\text { private well/spring }\end{array}$ & $59 / 59$ & 125 & 225 & 620 \\
\hline & Downgradient & $11 / 11$ & 854 & 892 & 1110 \\
\hline \multirow[t]{5}{*}{ Strontium } & Alluvial background & $15 / 15$ & 1.5 & 1.8 & 1.9 \\
\hline & Wasatch background & $10 / 10$ & 0.17 & 0.8 & 3.2 \\
\hline & Private well/spring background & $3 / 3$ & 1.9 & 2.1 & 2.1 \\
\hline & $\begin{array}{l}\text { Upgradient/crossgradient } \\
\text { private well/spring }\end{array}$ & $32 / 32$ & 0.3 & 2.4 & 3.5 \\
\hline & Downgradient & $4 / 4$ & 2.9 & 3.0 & 3.2 \\
\hline
\end{tabular}


Table 5.1 Summary of water quality for background and private water locations, Rifle, Colorado, sites (08/90 - 12/94) (Continued)

\begin{tabular}{|c|c|c|c|c|c|}
\hline \multirow[b]{2}{*}{ Constituent } & \multirow[b]{2}{*}{ Well groups ${ }^{c}$} & \multirow{2}{*}{$\begin{array}{c}\text { Frequency of } \\
\text { detection }^{d}\end{array}$} & Minimum & Median" & Maximum \\
\hline & & & \multicolumn{3}{|c|}{ (mg/L) } \\
\hline \multirow[t]{5}{*}{ Sulfate } & Alluvial background & $15 / 15$ & 443 & 855 & 977 \\
\hline & Wasatch background & $14 / 14$ & 49 & 1105 & 1440 \\
\hline & Private well/spring background & $6 / 6$ & 724 & 1070 & 2010 \\
\hline & $\begin{array}{l}\text { Upgradient/crossgradient } \\
\text { private well/spring }\end{array}$ & $59 / 59$ & 220 & 680 & 1580 \\
\hline & Downgradient & $11 / 11$ & 1100 & 2440 & 2710 \\
\hline \multirow[t]{5}{*}{ Uranium } & Alluvial background & $17 / 17$ & 0.017 & 0.027 & 0.046 \\
\hline & Wasatch background & $14 / 15$ & $<0.001$ & 0.005 & 0.036 \\
\hline & Private well/spring background & $6 / 6$ & 0.009 & 0.045 & 0.048 \\
\hline & $\begin{array}{l}\text { Upgradient/crossgradient } \\
\text { private well/spring }\end{array}$ & $66 / 68$ & $<0.0003$ & 0.025 & 0.057 \\
\hline & Downgradient & $12 / 12$ & 0.045 & 0.053 & 0.073 \\
\hline \multirow[t]{5}{*}{ Vanadium } & Alluvial background & $3 / 17$ & $<0.01$ & $<0.01$ & 0.05 \\
\hline & Wasatch background & $5 / 15$ & $<0.01$ & $<0.01$ & 0.08 \\
\hline & Private well/spring background & $1 / 6$ & $<0.01$ & $<0.01$ & 0.04 \\
\hline & $\begin{array}{l}\text { Upgradient/crossgradient } \\
\text { private well/spring }\end{array}$ & $25 / 68$ & $<0.01$ & $<0.01$ & 0.04 \\
\hline & Downgradient & $3 / 12$ & $<0.01$ & $<0.01$ & 0.09 \\
\hline \multirow[t]{5}{*}{ Zinc } & Alluvial background & $4 / 14$ & $<0.005$ & $<0.05$ & 0.29 \\
\hline & Wasatch background & $6 / 13$ & $<0.005$ & 0.009 & 0.051 \\
\hline & Private well/spring background & $3 / 5$ & 0.007 & $0.012^{f}$ & $<0.05$ \\
\hline & $\begin{array}{l}\text { Upgradient/crossgradient } \\
\text { private well/spring }\end{array}$ & $61 / 68$ & $<0.005$ & 0.070 & 2.5 \\
\hline & Downgradient & $11 / 12$ & 0.016 & 0.022 & 0.08 \\
\hline
\end{tabular}


Table 5.1 Summary of water quality for background and private water locations, Rifle, Colorado, sites (08/90 12/94) (Continued)

\begin{tabular}{|c|c|c|c|c|c|}
\hline \multirow[b]{2}{*}{ Constituent ${ }^{b}$} & \multirow[b]{2}{*}{ Well groups $^{c}$} & \multirow{2}{*}{$\begin{array}{l}\text { Number of } \\
\text { samples }^{d}\end{array}$} & Minimum & Median" & Maximum \\
\hline & & & \multicolumn{3}{|c|}{$(\mathrm{pCi} / \mathrm{L})$} \\
\hline \multicolumn{6}{|l|}{ Radionuclides } \\
\hline \multirow[t]{5}{*}{ Lead-210 } & Alluvial background & 2 & 1.4 & 1.9 & 2.3 \\
\hline & Wasatch background & 6 & 0.0 & 0.0 & 2.3 \\
\hline & $\begin{array}{l}\text { Private well/spring } \\
\text { background }\end{array}$ & 3 & 0.0 & 1.1 & 2.9 \\
\hline & $\begin{array}{l}\text { Upgradient/crossgradient } \\
\text { private well/spring }\end{array}$ & 51 & 0.0 & 1.6 & 17 \\
\hline & Downgradient & 6 & 0.5 & 1.4 & 2.8 \\
\hline \multirow[t]{5}{*}{$\begin{array}{l}\text { Net gross } \\
\text { alpha }\end{array}$} & Alluvial background & 16 & 0.0 & 2.3 & 34 \\
\hline & Wasatch background & 15 & 0.0 & 12 & 81 \\
\hline & $\begin{array}{l}\text { Private well/spring } \\
\text { background }\end{array}$ & 6 & 0.0 & 0.6 & 41 \\
\hline & $\begin{array}{l}\text { Upgradient/crossgradient } \\
\text { private well/spring }\end{array}$ & 68 & 0.0 & 4.7 & 33 \\
\hline & Downgradient & 12 & 0.0 & 6.2 & 32 \\
\hline \multirow[t]{5}{*}{ Polonium-210 } & Alluvial background & 2 & 0.0 & 0.0 & 0.0 \\
\hline & Wasatch background & 6 & 0.0 & 0.2 & 0.5 \\
\hline & $\begin{array}{l}\text { Private well/spring } \\
\text { background }\end{array}$ & 3 & 0.0 & 0.2 & 0.2 \\
\hline & $\begin{array}{l}\text { Upgradient/crossgradient } \\
\text { private well/spring }\end{array}$ & 51 & 0.0 & 0.1 & 7.0 \\
\hline & Downgradient & 6 & 0.0 & 0.0 & 1.7 \\
\hline \multirow[t]{5}{*}{$\begin{array}{l}\text { Radium-226/ } \\
-228\end{array}$} & Alluvial background & 16 & 0.0 & 0.5 & 2.5 \\
\hline & Wasatch background & 15 & 0.0 & 0.4 & 4.8 \\
\hline & $\begin{array}{l}\text { Private well/spring } \\
\text { background }\end{array}$ & 6 & 0.5 & 1.4 & 2.9 \\
\hline & $\begin{array}{l}\text { Upgradient/crossgradient } \\
\text { private well/spring }\end{array}$ & 68 & 0.0 & 0.8 & 11 \\
\hline & Downgradient & 12 & 0.1 & 1.1 & 4.0 \\
\hline
\end{tabular}


Table 5.1 Summary of water quality for background and private water locations, Rifle, Colorado, sites (08/90 - 12/94) (Concluded)

\begin{tabular}{|c|c|c|c|c|c|}
\hline \multirow[b]{2}{*}{ Constituent $^{\mathbf{b}}$} & \multirow[b]{2}{*}{ Well groups $^{\circ}$} & \multirow{2}{*}{$\begin{array}{c}\text { Number of } \\
\text { samples }^{d}\end{array}$} & Minimum & Median" & Maximum \\
\hline & & & \multicolumn{3}{|c|}{ (pCi/L) } \\
\hline \multirow[t]{5}{*}{ Thorium-230 } & Alluvial background & 2 & 0.0 & 0.2 & 0.4 \\
\hline & Wasatch background & 6 & 0.0 & 0.1 & 19 \\
\hline & $\begin{array}{l}\text { Private well/spring } \\
\text { background }\end{array}$ & 3 & 0.0 & 0.1 & 0.2 \\
\hline & $\begin{array}{l}\text { Upgradient/crossgradient } \\
\text { private well/spring }\end{array}$ & 51 & 0.0 & 0.1 & 1.8 \\
\hline & Downgradient & 6 & 0.0 & 0.1 & 0.3 \\
\hline
\end{tabular}

50th percentile of the data for a well group.

Inorganic constituents presented in this table were identified in the 1995 Baseline Risk Assessment as above background in ground water under the New Rifle site. Also included in this table are radionuclides monitored at the site.

'Well groups:

Alluvial background-Wells used in the 1995 baseline risk assessment (in preparation) to quantify alluvial background quality (RF0-01-0597, -0598, -0605, -0606), filtered water samples.

Wasatch background-Wells used in the 1995 baseline risk assessment to quantify shallow Wasatch background water quality (RFO-01-0620, -0622, and RFN-01-0641), filtered water samples.

Domestic background-Wells used in this position paper to quantify probable background water quality for the upgradient/crossgradient private water locations at New Rifle (RFO01-0573, -0436), unfiltered water samples.

Upgradient/crossgradient domestic-RFN-01-0421 through $-0427,-0430$ through -0433 , and -0435 , unfiltered water samples.

Downgradient-RFN-01-0428, unfiltered water samples.

dNumber of sample results reported at or above laboratory detection limit/total number of samples.

'Some data for these constituents were omitted for this table because they were nondetects with excessively high detection limits; they are flagged " $i$ " for matrix interference by the analytic laboratory.

'Value is the largest detected concentration in database for well group (larger values are all nondetects). 


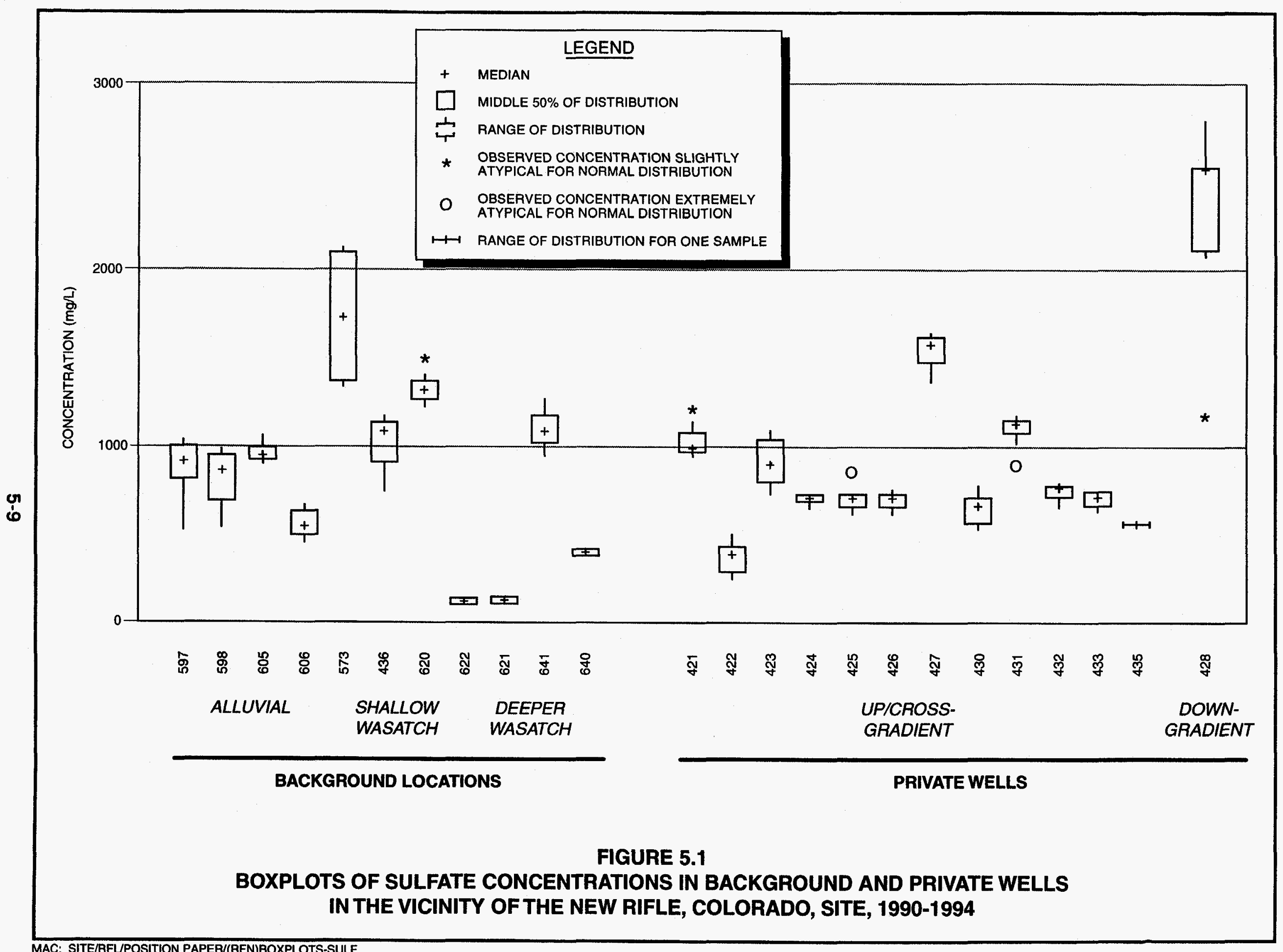




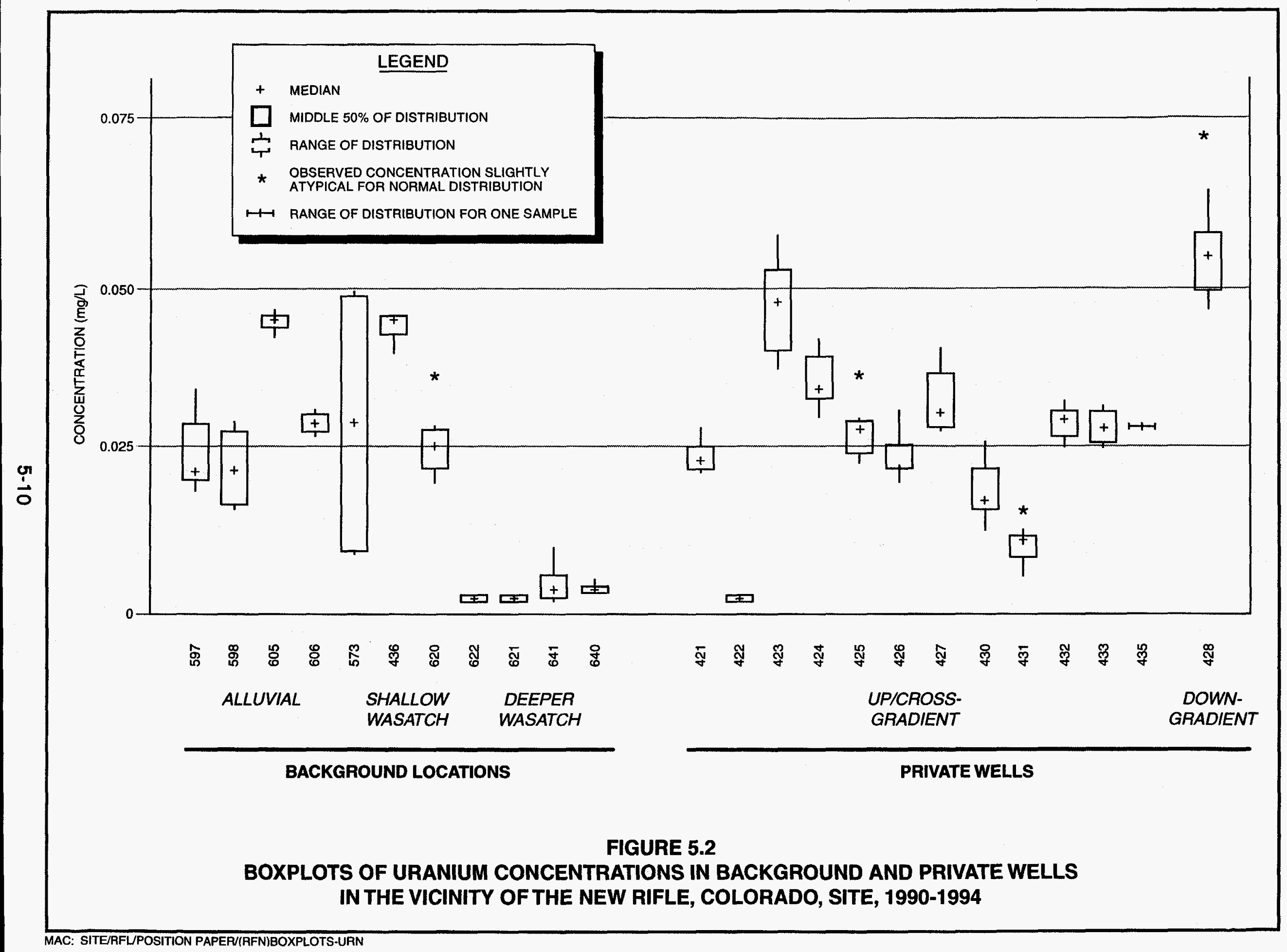




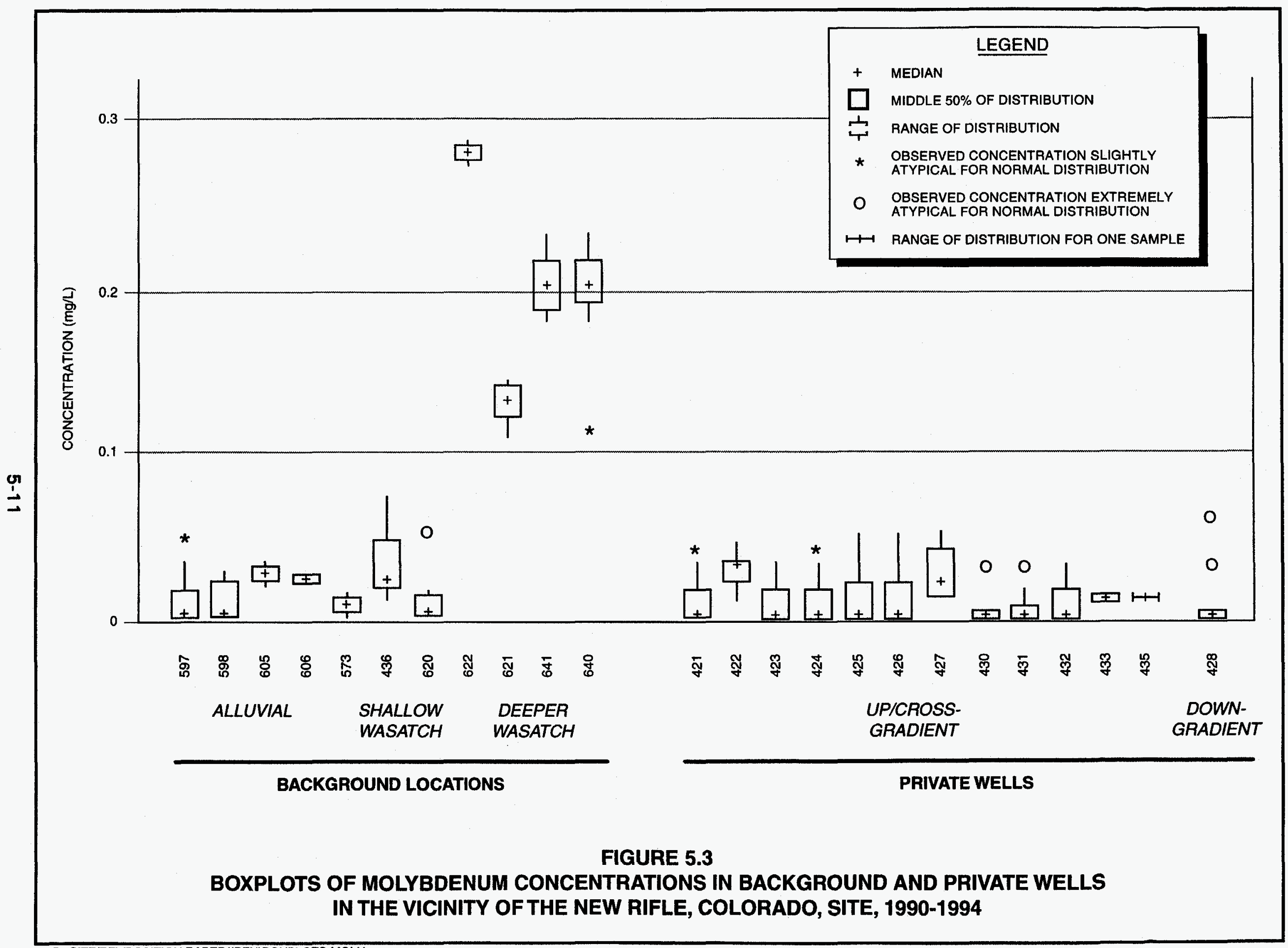




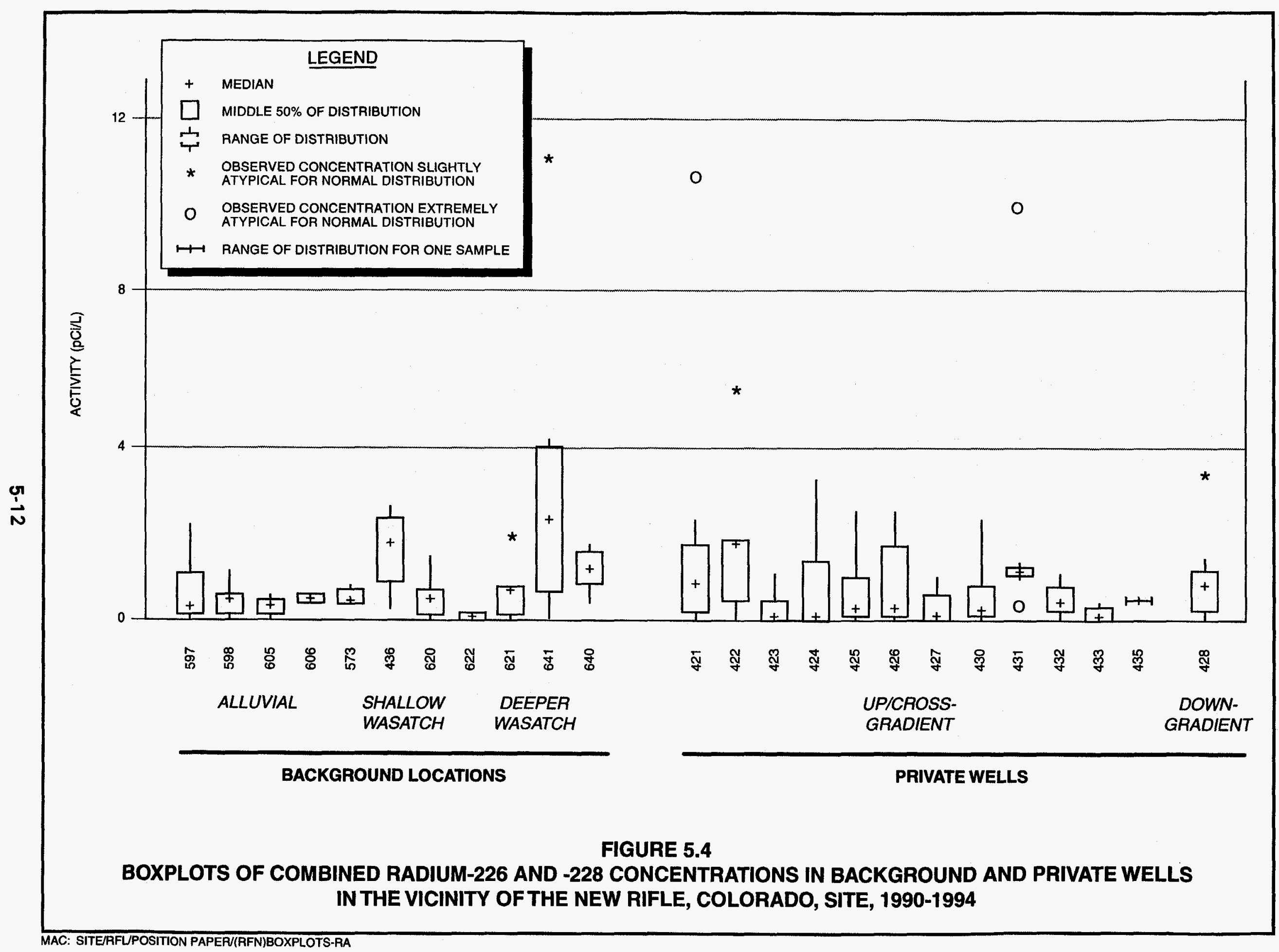


The figures indicate that uranium concentrations in groundwater in the vicinity of Rifle are commonly near the MCL of $0.044 \mathrm{mg} / \mathrm{L}$ and that sulfate concentrations in the area are almost always above the secondary MCL of $250 \mathrm{mg} / \mathrm{L}$. On the other hand, exceedences of the combined radium $\mathrm{MCL}$ of $5 \mathrm{pCi} / \mathrm{L}$ are anomalous events, and molybdenum concentrations are safely below the MCL of $0.1 \mathrm{mg} / \mathrm{L}$ except in the deeper Wasatch.

The statistical evaluation was performed to determine if one or more of the upgradient of crossgradient private wells may have higher concentrations of site contaminants than might be expected of a well or spring located in background conditions. The statistical testing method used was the Kruskal-Wallis test, followed if necessary by pairwise comparisons between background and individual private wells, as described in EPA (1989) and EPA (1992). The EPA recommends the use of the nonparametric Kruskal-Wallis test instead of Analysis of Variance (ANOVA) when distributional assumptions cannot be verified or when nondetects are present in the test datasets. Because EPA guidance specifies that wells should have at least three rounds of data for statistical testing, wells RFN-01-0433 and -0435 could not be evaluated statistically. Included private wells had a minimum of three rounds and up to 10 rounds of water quality data. The statistical testing was conducted at the 0.10 level of significance for each constituent. Tests conducted at the 0.10 level of significance have greater power to detect well differences than is possible using the more traditional 0.05 level of significance.

The statistical evaluations determined that iron, strontium, and zinc concentrations are higher in some of the private wells than in the background. However, these constituents are not effective indicators of contamination at the Rifle sites because all three are present at relatively low concentrations. On-site concentrations in the most contaminated wells average $17 \mathrm{mg} / \mathrm{L}$ for iron, $4.0 \mathrm{mg} / \mathrm{L}$ for strontium, and $0.58 \mathrm{mg} / \mathrm{L}$ for zinc. In contrast, the more mobile constituents chloride and nitrate are present at the Rifle sites in much higher concentrations (chloride averages $420 \mathrm{mg} / \mathrm{L}$ and nitrate averages $784 \mathrm{mg} / \mathrm{L}$ in the most contaminated wells). If iron, strontium, and zinc are site related, they should be accompanied by high levels of chloride and nitrate. Thus, iron, strontium, and zinc in private wells are from some other source. No other statistically significant elevations above background were identified among the upgradient and cross gradient wells and springs. This statistical analysis provides numerical support to the hydrological determination that the upgradient and crossgradient private well locations at Rifle have not been impacted by site activities. 


\subsection{CONCLUSIONS}

This position paper presents the following conclusions regarding the hydrogeochemical relationship between the New and Old Rifle processing sites and 15 domestic wells in their vicinity.

- None of the private wells or springs, with the possible exception of private well RFN01-0428, appear to have been impacted by former uranium processing-related activities. Private well RFN-01-0428, about 2.7 mile west of the New Rifle site is the only well that is clearly downgradient from the processing site. Impact to this well is uncertain because the extent of contamination to the west and southwest has not been fully characterized. Well RFN-01-0428 is not being used for drinking purposes. The other private water sources are hydraulically upgradient or crossgradient from the New Rifle site. Private well RFN-01-0427 is the well furthest west that was proposed for connection to the city of Rifle water system. Although this well is potentially crossgradient, water quality results indicate it has not been impacted by uranium processing-related activities. In addition, this well is not used for any purpose at this time and the presence of decaying organic material in the well has been reported by TAC personnel.

- Recent baseline risk assessment activities resulted in further definition of the Old and New Rifle site conceptual models. In particular, both ground water flow gradients and background water quality have been further characterized. Greater understanding of the sites has clarified the hydrogeochemical relationship between the Rifle processing sites and nearby private water wells and springs.

- Regional geologic data support the existence of natural contaminants in background water near Rifle. The probable source for the uranium and other metals (including chromium, vanadium, selenium), which are commonly associated with the occurrence of uranium deposits, is through Tertiary deposition of the Wasatch Formation. The ground water quality within the upper Wasatch Formation north or upgradient of the Rifle processing sites has been influenced by regional natural distribution of these metals and radionuclides. Markos and Bush (1983) sampled and analyzed ground water from five wells in a 50-square mile area near Rifle. All the wells were well away from the possible influence of uranium mill-related activities. Uranium and sulfate concentrations were within the range of background water quality near the Rifle sites and also within the range of sulfate and uranium concentrations detected in private wells and springs upgradient and crossgradient of the Rifle sites.

- There is additional evidence of the regional distribution of metals and radionuclides in the Wasatch Formation associated with uranium-bearing formations. Ground water sampled from wells completed in the Wasatch Formation before tailings disposal at the Estes Gulch Disposal site contains measurable levels of barium, uranium, selenium, lead, chromium, and vanadium, net gross alpha, and radium-226 and -228 combined. Selenium concentrations in ground water at Estes Gulch range from 0.022 to $0.975 \mathrm{mg} / \mathrm{L}$. The average selenium concentration was found to be 15 times greater 
than the EPA MCL of $0.01 \mathrm{mg} / \mathrm{L}$. Barium, cadmium, chromium, lead, molybdenum, net gross alpha, and radium-226 and -228 combined also exceed the EPA MCLs (DOE, 1992). Most of these constituents are also present in background water near the Rifle processing sites.

- At the Old and New Rifle sites, horizontal ground water in the alluvial aquifer and Wasatch Formation generally flows southwest. Biweekly water levels collected for more than 4 years from shallow alluvial well points in the area between the New Rifle tailings and many of the private wells and springs indicate gradients do not fluctuate significantly despite influences from the Colorado River. Vertical gradients between the alluvial aquifer and Wasatch Formation are generally slightly downward to nonexistent. The alluvial aquifer and upper weathered Wasatch Formation are considered part of the same flow system and are sometimes indistinguishable when water levels and water quality data are compared. Water levels taken at wells screened across different zones in the Wasatch Formation indicate the presence of multiple flow systems. Available water level data indicate the presence of at least four flow systems in the New Rifle site vicinity. Most private wells and springs are completed in or discharge from the upper Wasatch Formation along bedding surfaces or the alluvial aquifer/weathered upper Wasatch Formation. Background water quality data indicate that the upper Wasatch and alluvial aquifer/upper weathered Wasatch Formation flow systems are more elevated with respect to uranium and sulfate. Deeper flow systems in the Wasatch Formation tend to be very elevated with respect to chloride.

- Statistical analyses performed on all on-site and downgradient constituents of potential concern (including radionuclides), found to be above background in the most recent Rifle baseline risk assessment, indicate that constituents related to processing activities are not elevated above background in private wells and springs. Locations selected to define background for this assessment were based on environmental similarities with private wells and springs near the New Rifle site.

- Naturally occurring concentrations of hazardous constituents, including cadmium, selenium, uranium, and radium-226 and -228 combined exceed EPA MCLs. Cadmium, chloride, iron, lead, nitrate, manganese, sulfate, uranium, and zinc exceed Safe Drinking Water Act (SDWA) standards. Cadmium, nitrate, and selenium also exceeded state standards. 


\subsection{RECOMMENDATIONS}

This position paper presents the following recommendations regarding the hydrogeochemical relationship between the New and Old Rifle processing sites and 15 domestic wells in their vicinity.

- DOE should continue sampling well 0428 annually until the site observational work plan is completed. After the site observational work plan is complete, the potential impact to RFN-01-0428 should be reassessed.

- DOE should discontinue sampling all other private wells and springs north of Highway 6 or upgradient of the New Rifle site until the site observational work plan is completed.

- As part of the site observational work plan, DOE should evaluate the western extent of contamination from the New Rifle pile area. Also, when monitor wells are installed to reestablish ground water flow at the site after surface remediation is complete, a network of monitor wells should be completed in the alluvial aquifer and in the shallow Wasatch Formation north of the pile area and Highway 6 . These wells will be used to further define the conceptual model. 


\subsection{LIST OF CONTRIBUTORS}

The following individuals contributed to the preparation of this report.

\begin{tabular}{ll}
\hline Name & Contribution \\
\hline T. Monks & Hydrology, principal author \\
K. Smith & Statistics \\
D. Erskine & Geochemistry \\
J. Marshall & Risk Assessment \\
L. Sanchez & Word processing \\
V. Beck & Technical editing, document production coordinator \\
\hline
\end{tabular}




\subsection{REFERENCES}

DOE (U.S. Department of Energy), 1992a. Baseline Risk Assessment for Groundwater and Surface Water Contamination at the Uranium mill Tailings Sites in Rifle, Colorado, 050127.0000, July 1992, prepared by the U.S. Department of Energy, UMTRA Project Office, Albuquerque Operations Office, Albuquerque, New Mexico.

DOE (U.S. Department of Energy), 1992b. Remedial Action Plan and Site Design for Stabilization of the Inactive Uranium Mill Tailings Sites at Rifle, Colorado, DOE/AL050506.0000, February 1992, prepared by the U.S. Department of Energy, UMTRA Project Office, Albuquerque Operations Office, Albuquerque, New Mexico.

EPA (U.S. Environmental Protection Agency), 1989. Statistical Analysis of Ground-Water Monitoring Data at RCRA Facilities, interim final guidance, Office of Solid Waste/Waste Management Division, U.S. Environmental Protection Agency, Washington, D.C.

EPA (U.S. Environmental Protection Agency), 1992. Statistical Analysis of Ground-Water Monitoring Data at RCRA Facilities, addendum to interim final guidance, Office of Solid WasteMaste Management Division, U.S. Environmental Protection Agency, Washington, D.C.

Greensmith et al., 1971 Greensmith et al. (J. T. Greensmith, F. H. Hatch, R. H. Rastall), 1971. Petrology of the Sedimentary Rocks, Thomas Murby \& Company, London, England.

Sinnock, S., 1981. "Glacial Moraines, Terrace, and Pediments of Grand Valley, Colorado," in Western Slope Colorado, eds. R. C. Epis and J. F. Callendar, New Mexico Geological Society, 32nd Field Conference Guidebook, pp. 113-120.

Markos, G. and K. J. Bush, 1983. Data for the Geochemical Investigation of UMTRAP Designated Sites at Rifle Colorado, UMTRA-DOE/AL-0238, September 1983, prepared by Geochemistry and Environmental Chemistry Research, Inc., Rapid City, South Dakota.

Parkhurst et al. (D. L. Parkhurst, D. C. Thorstenson, and D. N. Plummer), 1980. PHREEQE - a computer program for Geochemical Calculations, U. S. Geological Survey, Water Resources Investigation 8-096, National Technical Information Services Report PB81-167-801, Springfield, Virginia. 